\title{
Analysis of the Spatial Distribution of Geology and Pedologic Formations in Gombe State, North Eastern Nigeria
}

\author{
Ikusemoran Mayomi $^{1}$, Didams Gideon ${ }^{2} \&$ Michael Abashiya $^{2}$ \\ ${ }^{1}$ Remote Sensing and GIS Unit, Department of Geography, University of Maiduguri, Borno State \\ ${ }^{2}$ Geomorphology Unit, Department of Geography, Gombe State University, Gombe State \\ Correspondence: Didams Gideon, Geomorphology Unit, Department of Geography, Gombe State University, \\ Gombe State. E-mail: gdamsviva@gmail.com
}

Received: October 9, 2017

Accepted: October 18, 2017

Online Published: February 27, 2018

doi:10.5539/jgg.v10n1p83

URL: http://dx.doi.org/10.5539/jgg.v10n1p83

\begin{abstract}
This paper focused on the mapping and analysis of the spatial distribution of the geology and soils in Gombe State. The ever rapid rise in population of the country has called for the need for expansion of agricultural activities which necessitates an in-depth knowledge of the spatial location of soil types for agricultural related activities. There is also the need to explore the environment for possible endowments of mineral resources which can be exploited to meet the economic demands of the populace. The soil and geology maps of Gombe State were extracted from existing soil and geology maps of Nigeria, obtained from Food and Agricultural Organization (FAO)/United Nations Education, Scientific and Cultural Organization (UNESCO)/International Soil Reference and Information Center (ISRIC) and Nigeria Geological Survey Agency (NGSA) respectively. The soil and geology types were digitized as polygon, while other important features such as LGA boundaries, state boundaries were also digitized and overlain on the two generated maps (soils and geology). The clip sub module of the ArcGIS was used to delineate each of the LGAs in both maps, that is, extraction of each LGA as well as the soil and geology units in each of the LGAs. The area in square kilometers of the soils and geology units in the entire state and in each LGA were obtained through the use of the area calculation module of the ArcGIS. The result of the study revealed that Gombe State consists of fourteen (14) geologic units. Among them, the KerriKerri which comprised of sandstone, shale and clay geologic unit covers almost half $(42.75 \%)$ of the State. Limestone and Shale of the Pindiga formation which are principally used for cement making are found mainly in Funakaye LGA which is the home of Ashaka Cement. It was also found out that there are eleven soil units in the state with Nitisols almost covering half of the state. It was recommended that the generated soil and geologic maps of the State are expected to be considered for mineral exploration and crop suitability assessments in order to reduce time, cost and energy that would likely be incurred if the entire state is assessed.
\end{abstract}

Keywords: mapping and analysis, spatial distribution, Gombe State

\section{Introduction}

The importance of the study of the soils and geology of any place cannot be overemphasized. For instance, in the case of geology, (Rhodes \& Perlman, 2001) reported that almost everything we utilize in our lives has something to do with earth and that, although, the sun is the ultimate energy source of earth, we rely on "earth" energy sources for our daily energy requirements like oil, carbon, nuclear energy obtained from uranium, among others. Geology science is of paramount importance to locate those earth energy sources, how to extract them from earth more efficiently and at a lower cost, and with the smallest impact on the environment. Water, an important natural resource, is scarce in many parts of the world. The study of geology can help to find underground water resources to reduce the impact of water scarcity of people and civilization. Moreover, the spatial distribution of the geology of an area also helps in the assessments, monitoring and prediction of possible environmental hazards in the area. Among these hazards are floods, soil erosion, droughts earthquake among others. The knowledge of geology can help by estimating where earthquakes are most likely to occur (known as fault lines) and to recommend the type of technology to be used in the construction of buildings in these vulnerable areas (Rhodes \& Perlman, 2001). Finally, most countries of the world depend heavily on the available mineral resources in their domain for their growth and development. The endowments of these mineral resources largely depend on the geology and the soil types of the area. 
Soil is one of the most important natural resources that are available in almost everywhere. It is normally the major determinant of so many human activities. For instance, farmers consider its types, fertility and texture among others for site suitability for their various crops production, civil engineers relate soil types to residential development, the availability of some mineral resources also largely depend on the soil types. Soil Science Society of America (2017) stated that soil is a vital part of the natural environment, and it is just as important as plants, animals, rocks, landforms, lochs and rivers. It influences the distribution of plant species and provides a habitat for a wide range of organisms. It controls the flow of water and chemical substances between the atmosphere and the earth, and acts as both a source and store for gases (like oxygen and carbon dioxide) in the atmosphere. Soils not only reflect natural processes but also record human activities both at present and in the past. They are therefore part of our cultural heritage. According to FAO (2002), a better understanding of the linkages between soil life and ecosystem function and the impact of human interventions will enable the reduction of negative impacts and the more effective capture of the benefits of soil biological activity for sustainable and productive agriculture. Hence, spatial distribution of soil is very important to so many disciplines that rely on such spatial data for decision making.

Existing comprehensive research on the soils and geology of Gombe State is very scanty. Most of the existing works are either on North East Nigeria as a region, or former Bauchi State; the region and State respectively which Gombe State belonged until 1996 when it was made a state. Other existing ones are based on the geographical regions like Benue Basin, Upper Benue Basin or Gongola Basin (Udo, 1978) where Gombe State is located. Being one the most recent States that was created in Nigeria, expectedly, existing research on such states cannot be as much as those that have existed for long. There has been recent works on the physical aspects of the State especially since the advent of security challenges in the entire North East region of Nigeria which necessitated the study of the topography of the State (Ikusemoran et al., 2017). The ever rapid rise in population of the country has also called for the need for expansion of agricultural activities which necessitates an in-depth knowledge of the soil types for agricultural related studies such as suitability study for crop production among others. There is also the need to explore the environment for possible endowments of mineral resources which can be exploited to meet the demands of the populace. Hence the need for the study of the spatial distributions of the soil and geology of a young state like Gombe state becomes very necessary.

Moreover, most existing maps are on the entire country or at best on States especially the old regions and States, and hence making it difficult for people in a country where Geographical Information System (GIS) techniques is relatively new (Surveyor General of the Federation (OSGOF) 2012) to delineate or extract smaller areas of interest like LGAs from the existing maps. Finally, a recent publication on the terrain of Gombe state (Ikusemoran et al., 2016) contains a comprehensive analysis of the topography, drainage, vegetation, transportation and settlements of the state. The Soils and Geology of the State were not discussed in the publication resulting to several calls by stake holders to work on the two missing features for the benefit of the general public. It is based on this background that this paper was set to map and analyze the spatial distribution of soil and geology in Gombe State. The main objectives are therefore, to: (i) Generate digital maps and analysis of the spatial distribution of the soils and geology of Gombe State. (ii) Delineate and analyze the spatial distribution of the soils and geology in each of the Local Government Areas of Gombe State.

\section{The Study Area}

According to (Ikusemoran et al., 2016) Gombe State which is popularly referred to as the 'Jewel in the Savannah' was carved out from the former Bauchi State by the Federal Military Government of Nigeria on $1^{\text {st }}$ October, 1996. The State shares boundaries with Yobe State to the north, Adamawa and Taraba States to the south, Borno State to the east, and Bauchi State to the west (Fig.1). The following tribes are also found in the State: Tangale, Waja, Fulani, Tula, Cham, Dadiya, Hausa. In (Gombe State Official Website. 2013), the topography of Gombe State is made up of mainly mountainous, undulating and hilly to the south-east and flat opens plains in the weatern part of the State. (Gombe State Tourism Board. 2013) also described the hills of Gombe State as having beautiful domeshaped rock formations with fascinating scenery which are ideal for climbing and camping. The Famous Tangale dome shaped rock/hill formation, Tula Hills, the Bima hills as well as Filiya - Dadiya hills and the Ndinijam Kargo hill are some of the hills in these mountainous region.

In the study of (Ikusemoran et al., 2016), most parts of the State are located within the valley of River Gongola and on some highlands and mountain ranges. The river basin is a generally lowland area with altitudes ranging from 184 to $351 \mathrm{~m}$ heights above sea level. They concluded that more than $33 \%$ of the land of Gombe State lies within the Gongola valley. This River Gongola valley formed an east-west narrow land area in Dukku and Nafada LGA at the extreme northern part of the State, and except the intrusion of Kulani-Degri-Likkar hills in the southern part of the state, the entire western border of the state comprised the river basin. 


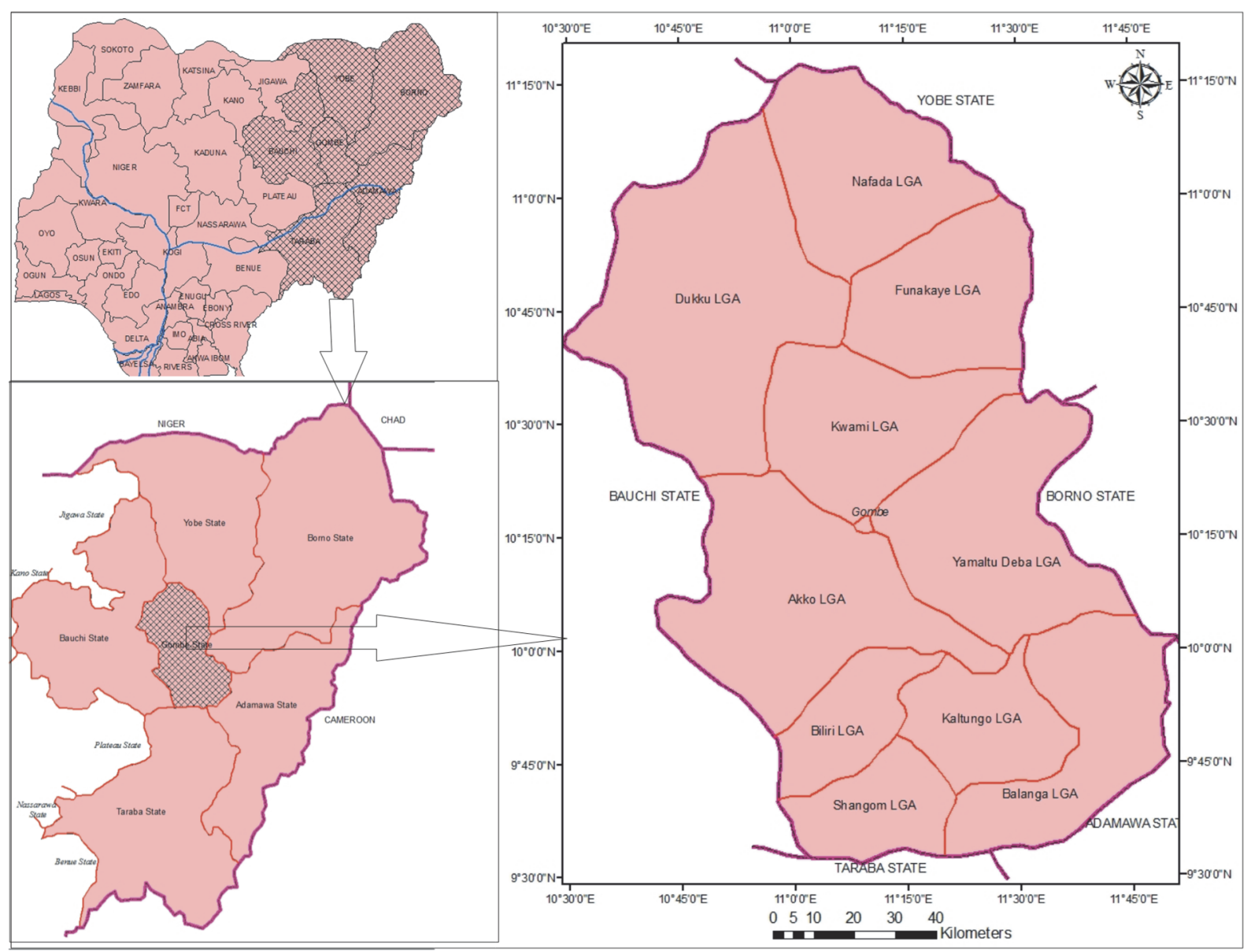

Figure 1. The Study Area

The northern part of Dukku LGA, the central portion of Nafada LGA, the western part of Funakaye and Kwami LGAs, major parts of Yamaltu LGA and the north and southern parts of Balanga LGA are all located in the valley of River Gongola (Fig.2). The highest peak of the highlands in Gombe State is Kilang hill in Shangom LGA with altitude of $1158 \mathrm{~m}$ above the sea level. Only $5.8 \%$ of the land areas of Gombe State are of highlands, with Kaltungo, Balanga and Shongom LGAs having more than $10 \%$ of their land area as highlands. Some of the highlands/hills in the state with their maximum heights as derived from the Digital Elevation Models (DEM) in Fig. 2 are shown in Table 1.

Table 1. Highlands/Hills and their maximum peaks in Gombe State

\begin{tabular}{llll}
\hline S/N & Highlands/Hills & LGAs & Highest Peak (m) \\
\hline 1 & Kilang & Shangom & 1158 \\
2 & Filiya & Shangom & 1062 \\
3 & Dadiya & Balanga & 1029 \\
4 & Nwona & Balanga & 913 \\
5 & Kilani-Degil-Jikkani & Balanga & 891 \\
6 & Bima & Yamaltu Deba & 885 \\
7 & Tangale & Biliri & 882 \\
8 & Dogon Dutse & Kaltungo & 845 \\
9 & Tula & Kaltungo & 840 \\
10 & Nappe & Akko & 729 \\
11 & Chabbal & Akko & 678 \\
12 & Pindiga & Akko & 663 \\
13 & Bworo & Nafada & 525 \\
\hline
\end{tabular}


River Gongola is the largest and the most important river in the State. The River enters the State in the north-west through Bauchi State and flows eastward through Dukku, and Nafada LGAs. At Nafada, the Gongola bends in a loop southward forming natural boundary between the state and Borno and Adamawa states in the eastern parts before it joins River Benue at Numan, outside the state (Ikusemoran et al., 2016). According to (Abubakar, 2013), Gombe state has two distinct climates, the dry season (November-March) and the rainy season (April-October) with an average rainfall of $850 \mathrm{~mm}$. The mean annual temperature is about $32^{\circ} \mathrm{C}$, while the vegetation of the state is that of savanna woodland comprising scattered shrubs and trees such as Butyrospermum, paradoxum, Tamarin indica, Parkia biglibosa, Aflexia Africana and grasses. The National Population and Housing Census of Nigeria (National Population Commission. 2006) put the total population of the State as 2,365,040 people out of which $1,244,228$ were males and 1,120,802 were females. (Mohammed, 2011) reported that the main occupation of the people in the state is small-scale farming and the major crops grown include rice, maize, cowpea and vegetables.

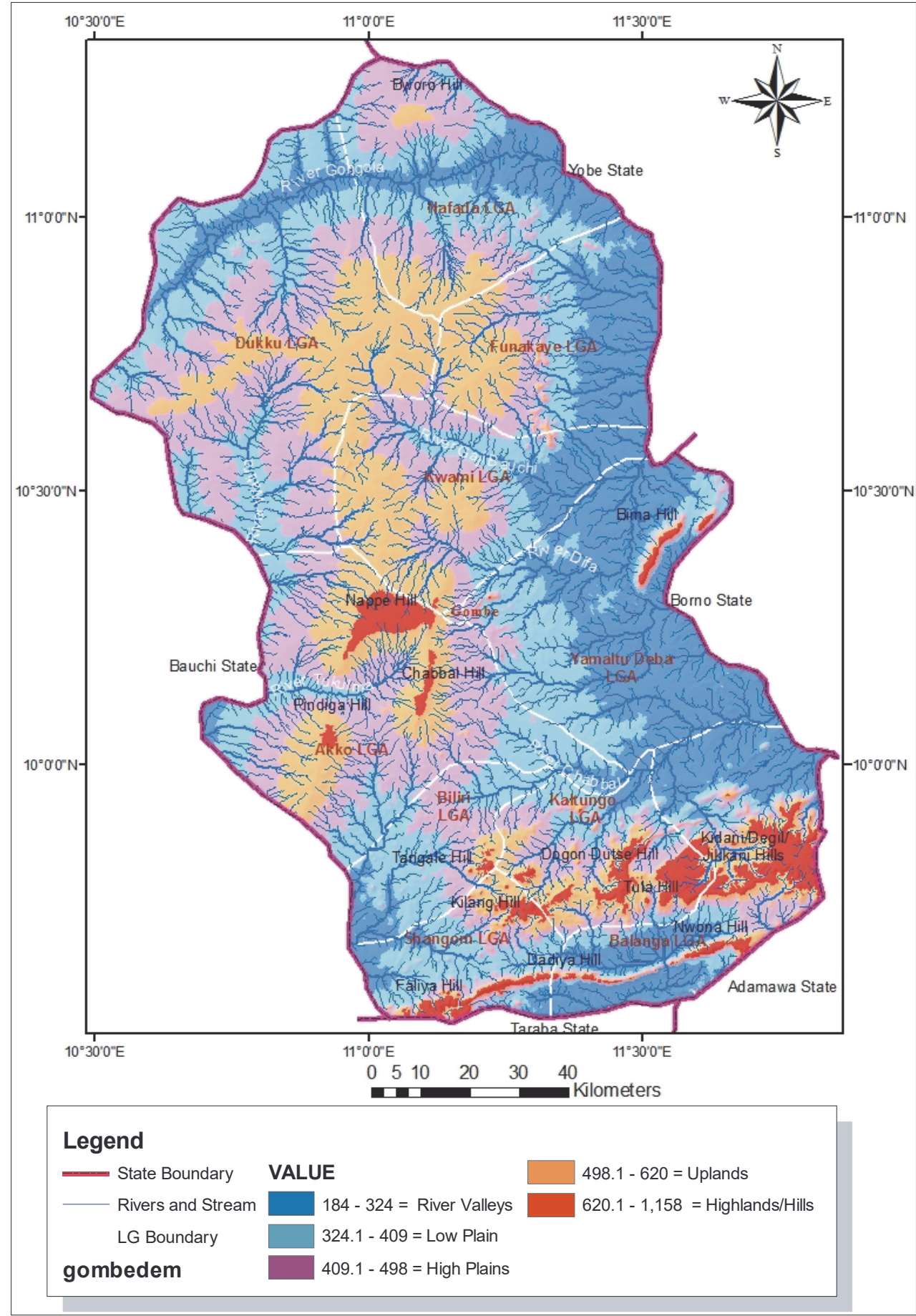

Figure 2. Relief and Drainage of Gombe State 


\section{Materials and Methods}

Table 2 shows the acquired, sources and the usefulness of the data for this paper.

Table 2. Types, sources and importance of acquired data

\begin{tabular}{lll}
\hline Data & Sources & Importance \\
\hline Soil Map of Nigeria & $\begin{array}{l}\text { FAO }^{*} \text { and UNESCO*/ISRIC } \\
(1996)\end{array}$ & $\begin{array}{l}\text { Base map for extraction of the Soil map of Gombe } \\
\text { State }\end{array}$ \\
Geology Map of Nigeria & $\begin{array}{l}\text { Base map for extraction of the Geology map of } \\
\text { Gombe State }\end{array}$ \\
$\begin{array}{l}\text { Political Map of Gombe } \\
\text { State }\end{array}$ & $\begin{array}{l}\text { Dada et al (2007) } \\
\text { Nigeria Geological Survey } \\
\text { Agency (NGSA) (2009) } \\
\text { boundaries for extraction of each of the LGAs }\end{array}$ \\
$\begin{array}{l}\text { Settlements in Gombe } \\
\text { State }\end{array}$ & $\begin{array}{l}\text { Encarta Premium (2009) } \\
\text { To link with the generated maps in order to see the } \\
\text { location of some settlements in each LGAs of the } \\
\text { State }\end{array}$ \\
\hline
\end{tabular}

*Food and Agricultural Organization (FAO), *United Nations Education, Scientific and Cultural Organization (UNESCO), *International Soil Reference and Information Center (ISRIC), *Nigeria Geological Survey Agency (NGSA)

The acquired soils and geology maps of Nigeria were separately georeferenced using the World's WGS 1984 projection system, with some selected settlements as tie points. Gombe State political map was also referenced to the georeferenced soils and geology maps of Nigeria. Each of the LGAs in the State was digitized using the complete polygon module after the first digitized polygon (LGA) was done as new. The soil and geology types were digitized as polygon, while other important features such as LGA boundaries, state boundaries were also digitized and overlain on the two generated maps (soils and geology) as shown in Figs 3 and 5. The clip sub module of the ArcGIS was used to delineate each of the LGAs in both maps, that is, extraction of each LGA as well as the soil and geology units in each of the LGAs as shown in Figs. 4a-4k and 6a -6k. The area in square kilometers of the soils and geology units in the entire state and in each LGA was obtained through the use of the area calculation module of the ArcGIS. The results were used to prepare Tables 3 and 4.

\section{Spatial Analysis of the Geology of Gombe State}

Gombe State consists of fourteen (14) geological units: (i) Alluvium (ii) Basalt (iii) Coarse Porphyritic Homblende Granite (iv) Undifferentiated Granite, Migmatite \& Granite Gneis (v) Migmatite and Granite Gneis (vi) Porphyritic Granite (vii) Coarse Porphyritic Biotite (viii) Shale and Minor Sandstone (ix) Older Basalt (x) Shale Sandstone and Limestone (xi) Sandstone, Siltstone and Shale (xii) Shale, Limestone and Sandstone (xiii) Shale and Mudstone (xiv) Sandstone, Siltstone, Shale, Coal and Ironstone. All these geologic units belonged to twelve rock formations (NGSA) as classified in Table 2.

Table 3. Rock formations, age and the geologic units in Gombe State

\begin{tabular}{lll}
\hline Formation & Age & Geologic Units \\
\hline Alluvium & & Alluvium \\
Basalt & Cretaceous* & Basalt \\
Basement & Pre Cambrian $*$ & Coarse Porphyritic Homblende Granite \\
Complex & & Undifferentiated Granite, Migmatite and Granite \\
& & Gneis \\
& & Porphyritic Granite, Coarse Porphyritic Biotite \\
Jessu & Upper Turonian ** & Shale and Minor Sandstone \\
Longuda Basalt & Tertiary - Recent Volcanics ** & Older Basalt \\
Pindiga & Turonian-Coniacian $* * *$ & Shale Sandstone and Limestone \\
Bima & Albian to Early Cenomanian* & Sandstone, Siltstone and Shale \\
Yolde & Late Albian - Late Cenomanian * & Shale, Limestone and Sandstone \\
Fika & Late Cretaceous $* * *$ & Shale and Mudstone \\
Gongila & Turonian-Coniacian $* * *$ & Limestone and Shale \\
\hline
\end{tabular}




\begin{tabular}{ll}
\hline $\begin{array}{l}\text { Gombe } \\
\text { Sandstone }\end{array}$ & Maastrichtian age $*$ \\
KerriKerri $\quad$ Post-Cretaceous * & Sandstone, Siltstone, Shale, Coal and Ironstone \\
\hline$*($ Ahmed, 2007) & \\
$* *$ (Carter et al., 1963) & \\
$* * *$ (Akande et al., 1998) & \\
$* * * *$ (Portland Cement. 2017) &
\end{tabular}




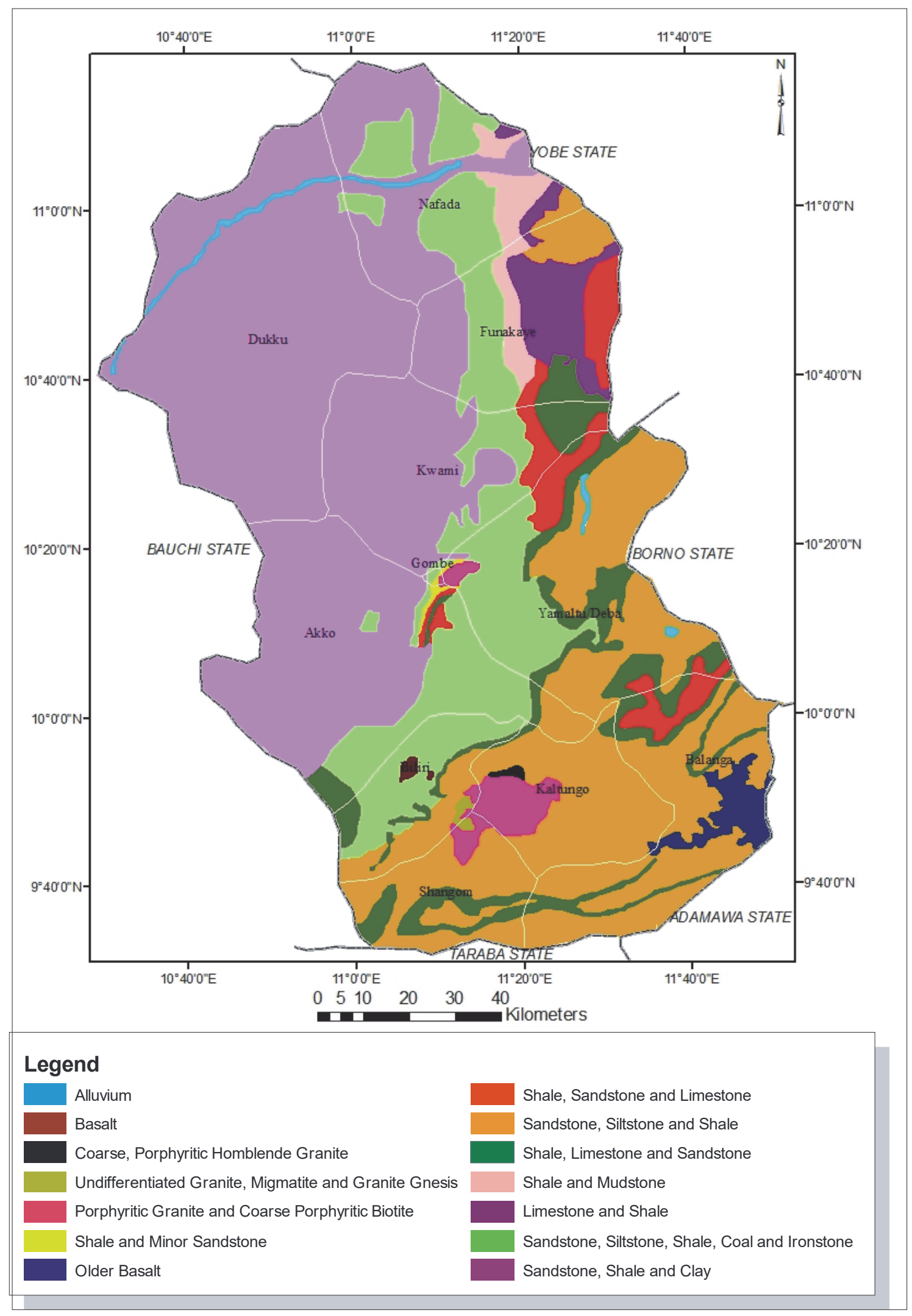

Figure 3. Geologic Units in Gombe State

Gombe State is known for cement production following the presence of limestone deposit in the State. Fig. 3 revealed that there are three geologic units that contain limestone which is principally used for cement production 
in the State; Limestone and Shale of the Pindiga formation, Shale limestone and Sandstone of the Yolde formation as well as Shale, Sandstone and Limestone of the Pindiga formation. These three geological units are found in the north eastern region of the state. While Limestone and Shale of the Pindiga formation are mainly found in Funakaye LGA (with little extension to Nafada LGA), the other two formations are situated in Balanga, Funakaye, Nafada, Kwami and Yamaltu Deba LGAs.

The most common rock types used in cement production are: limestone which supplies the bulk of the lime and clay, marl or shale which supplies the bulk of the silica, alumina and ferric oxide Portland Cement (2017). The extensive endowment of Limestone and Shale in Funakaye LGA was no doubt the main reason of the siting of Ashaka Cement factory in Ashaka in Funakaye LGA in Gombe State. Therefore, villages like Jillahi, Zagaina, Zadawa and Madekiri, Ungwan Yeyaro in Funakaye LGA and Jombor and western Manawashi in Nafada LGA are all situated in Limestone region.

Table 4. Spatial Distribution of the Geologic Units in each LGA in Gombe State

\begin{tabular}{|c|c|c|c|c|c|c|c|c|c|c|c|c|c|c|}
\hline LGAs & Alluvium & Basalt & Coarse PHG* & Undiff GMG* & $\begin{array}{l}\text { PorphyrGCPB } \\
*\end{array}$ & \begin{tabular}{|l} 
Shale \& \\
Minor \\
Sandstone
\end{tabular} & Older Basalt & \begin{tabular}{|l}
$\begin{array}{l}\text { Shale } \\
\text { Sandstone }\end{array}$ \\
\& Limestone
\end{tabular} & \begin{tabular}{|l} 
Sandstone \\
$\begin{array}{l}\text { Siltstone \& } \\
\text { Shale }\end{array}$ \\
\end{tabular} & $\begin{array}{l}\text { Shale, } \\
\text { Limestone \& } \\
\text { Sandstone }\end{array}$ & \begin{tabular}{|l} 
Shale \& \\
Mudstone
\end{tabular} & $\begin{array}{l}\text { Limestone \& } \\
\text { Shale }\end{array}$ & \begin{tabular}{|l} 
Sandstone, \\
Siltstone, \\
Shale, Coal \& \\
Ironstone
\end{tabular} & $\begin{array}{l}\text { Sandstone, } \\
\text { Shale \& Clay }\end{array}$ \\
\hline & Alluvium & Basalt & \multicolumn{3}{|c|}{ Basement Complex } & Jessu & \begin{tabular}{|l|} 
Longuda \\
Basalt
\end{tabular} & Pindiga & Bima & Yolde & Fika & Gongola & Gombe & Kerikeri \\
\hline & Formation & Formation & \multicolumn{3}{|l|}{ Formation } & Formation & Formation & Formation & Formation & Formation & Formation & Formation & Formation & Formation \\
\hline Akko & & & & 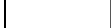 & | & 13.69 & & 34.19 & 86.56 & 90.99 & & & 601.36 & 1726.78 \\
\hline 2553.57 & & & & & & $0.54 \%$ & & $1.34 \%$ & $3.39 \%$ & $3.56 \%$ & & & $23.55 \%$ & $67.62 \%$ \\
\hline Balanga & & & & & & & 216.01 & 114.56 & 1041.31 & 294.92 & & & & \\
\hline 1666.48 & & - & - & - & - & - & $12.96 \%$ & $6.87 \%$ & $62.47 \%$ & $17.69 \%$ & - & - & - & - \\
\hline Biliri & & 18.77 & & 13.89 & 12.3 & & & & 237.24 & 97.73 & & & 394.09 & \\
\hline 774.02 & & $2.43 \%$ & & $1.79 \%$ & $1.59 \%$ & & & & $30.65 \%$ & $12.63 \%$ & & & $50.91 \%$ & \\
\hline Dukku & & & & & 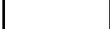 & | & & 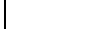 & 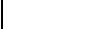 & 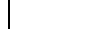 & & & 6.87 & 3357.61 \\
\hline 3364.48 & & & & [- & 5 & - & $5^{-}$ & - & $5^{\circ}$ & $j^{-}$ & $5^{-}$ & - & $0.20 \%$ & $99.80 \%$ \\
\hline Funakaye & & . & & 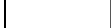 & | & 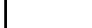 & & 191.34 & 153.38 & 84.8 & 131.19 & 364.9 & 287.36 & 262.71 \\
\hline 1475.68 & & & & 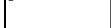 & $5^{-}$ & [- & 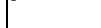 & $12.97 \%$ & $10.40 \%$ & $5.75 \%$ & $8.89 \%$ & $24.73 \%$ & $19.47 \%$ & $17.80 \%$ \\
\hline Gombe & & & & & 1.56 & 3.23 & & & & & & & 6.56 & 2.44 \\
\hline 13.79 & & - & - & - & $11.31 \%$ & $23.42 \%$ & - & - & - & - & - & - & $47.57 \%$ & $17.69 \%$ \\
\hline Kaltungo & & & 14.41 & & 182.5 & & 3.15 & & 772.17 & 25.43 & & & & \\
\hline 997.66 & & & $1.44 \%$ & & $18.29 \%$ & & $0.32 \%$ & & $77.40 \%$ & $2.55 \%$ & & & ] & $5^{-}$ \\
\hline Kwami & & & & & & & & 94.63 & & 105.81 & & & 269.36 & 1162.69 \\
\hline 1632.49 & & & & & & & & $5.80 \%$ & & $6.48 \%$ & & & $16.50 \%$ & $71.22 \%$ \\
\hline Nafada & 30.34 & & D. & & | & & D. & 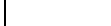 & 38.5 & & 167 & 62.44 & 610.3 & 857.97 \\
\hline 1766.55 & $1.72 \%$ & & & & & & & & $2.18 \%$ & & $9.45 \%$ & $3.53 \%$ & $34.55 \%$ & $48.57 \%$ \\
\hline Shangom & & & & 8.1 & 48.43 & & & & 494.05 & 268.3 & & & & D. \\
\hline 818.88 & & & & $0.99 \%$ & $5.91 \%$ & & & & $60.33 \%$ & $32.76 \%$ & & & 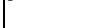 & 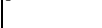 \\
\hline Y/Deba & 20.81 & & & & 27.15 & 6.29 & & 157.77 & 952.05 & 449.69 & & & 573.94 & 7.3 \\
\hline 2195 & $0.95 \%$ & & & & $1.24 \%$ & $0.29 \%$ & & $7.19 \%$ & $43.37 \%$ & $20.49 \%$ & & & $26.15 \%$ & $0.33 \%$ \\
\hline Total & 51.15 & 18.77 & 14.41 & 21.99 & 271.94 & 23.21 & 219.16 & 592.49 & 3775.26 & 1417.67 & 298.19 & 427.34 & 2749.84 & 7377.5 \\
\hline G/Total & & $0.11 \%$ & $0.08 \%$ & $0.13 \%$ & $1.58 \%$ & $0.13 \%$ & $1.27 \%$ & $3.43 \%$ & $21.87 \%$ & $8.21 \%$ & $1.73 \%$ & $2.48 \%$ & $15.93 \%$ & 17258.9 \\
\hline Total & $0.30 \%$ & & & & & & & & & & & & & $42.75 \%$ \\
\hline G/Total & & & & & & & & & & & & & & $100 \%$ \\
\hline
\end{tabular}

${ }^{*}$ Coarse PHG $=$ Coarse Porphyritic Homblende Granite, ${ }^{*}$ UndiffGMG $=$ Undifferentiated Granite, Migmatite \& Granite Gneis, * PorphyrGCPB*= Porphyritic Granite, Coarse Porphyritic Biotite

Among all these rock formations, the KerriKerri which comprised of sandstone, shale and clay geologic unit covers almost half (42.75\%) of the State as revealed in Fig. 4 and Table 4 which is very similar to the report of (Gombe State Official Website. 2013) that half of Gombe State is underlain by the early tertiary KerriKerri Formation. The western part of the state, that is, $99.8 \%$ of Dukku LGA, more than half of the land areas of Akko and Kwami LGAs (62.67\% and $71.22 \%$ respectively). Two other geological units, that is, Sandstone, Siltstone and Shale of Bima formation as well as Sandstone, Siltstone, Shale, Coal and Ironstone of Gombe formation also cover large areas of the State with $21.87 \%$ and $15.93 \%$ respectively. According to Klinkenberg (1967), Yolde Formation gives rise to a subdued topography often with sparse vegetation cover and is poorly exposed in most part of the Gongola basin. The Yolde Formation is indeed a transitional sequence between the continental Bima Group and the marine deposits of the lower part of the Pindiga Formation which is noticeable in Balanga, Funakaye, Nafada, Yamaltu Deba and other parts of the state as shown Fig. 3. (Suleiman et al., 2015) also reported that the exposed stratigraphic succession in the Ashaka area begins with the Bima Sandstone. It also forms the floor of the Ashaka Cement Quarry section and is separated from the overlying Pindiga Formation (Kanawa Member) by a thin ferruginous crust without the transitional Yolde Formation. The Yolde Formation is almost absent in the Ashaka area. 
The spatial disribution of the geologic units in each LGA of the State was quantified as presented in Table 4, while the spatial distribution of the geology in each of the eleven LGAs are also presented in Figs. 4a to Figs. 4k.

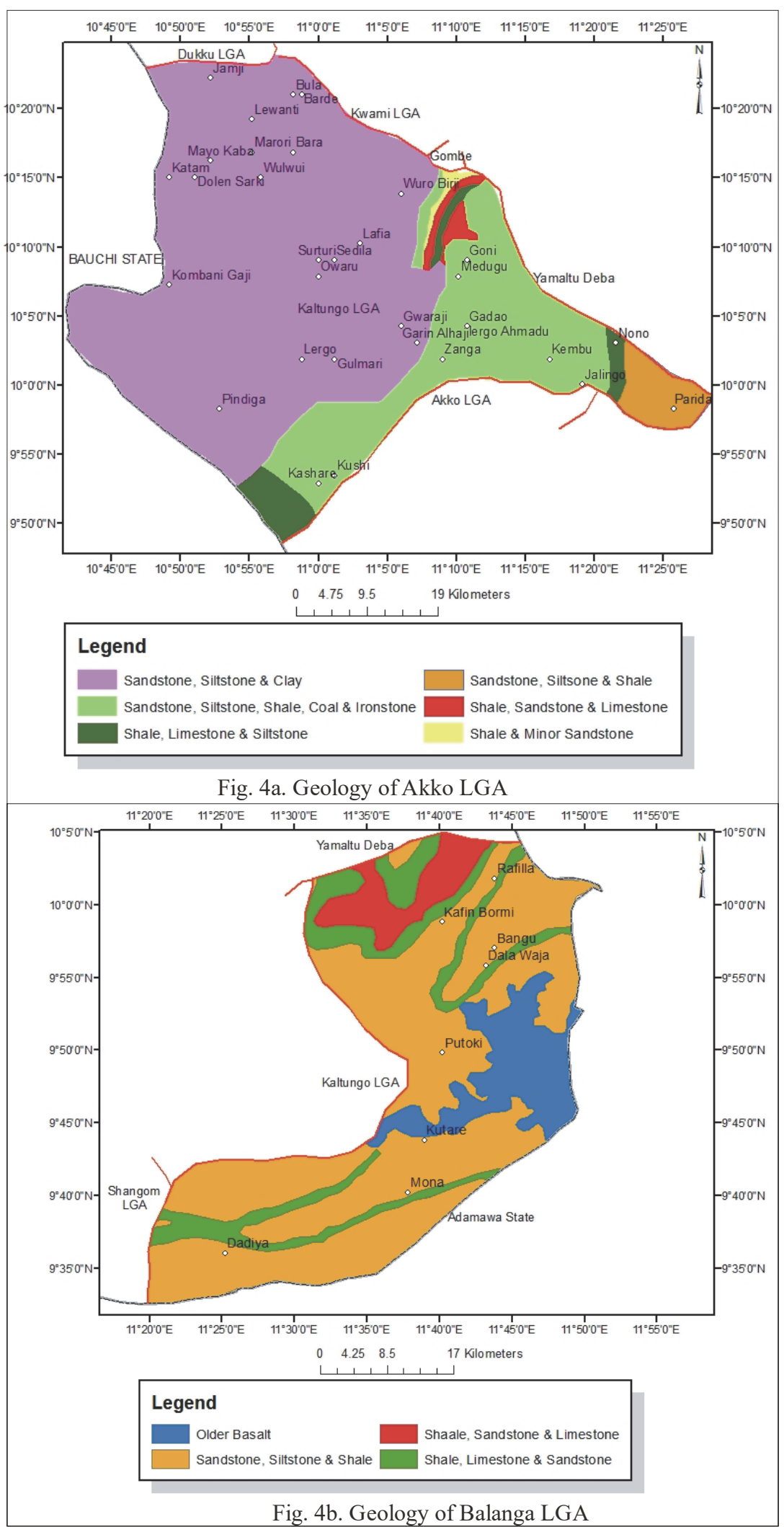

Figure 4a\&4b. Geology of Akko \& Balanga LGAs 


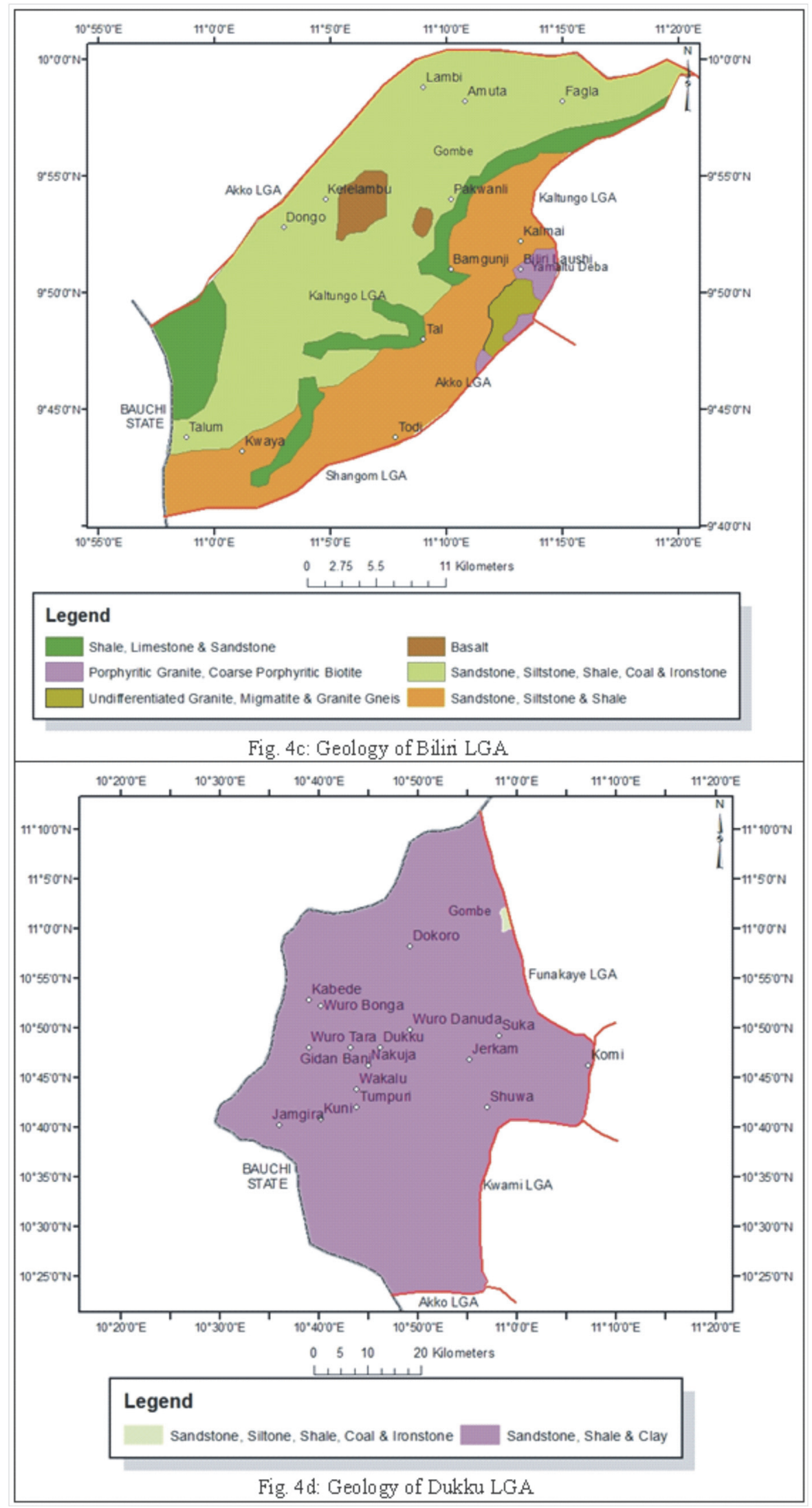

Figure 4c\&4d. Geology of Biliri \& Dukku LGAs 


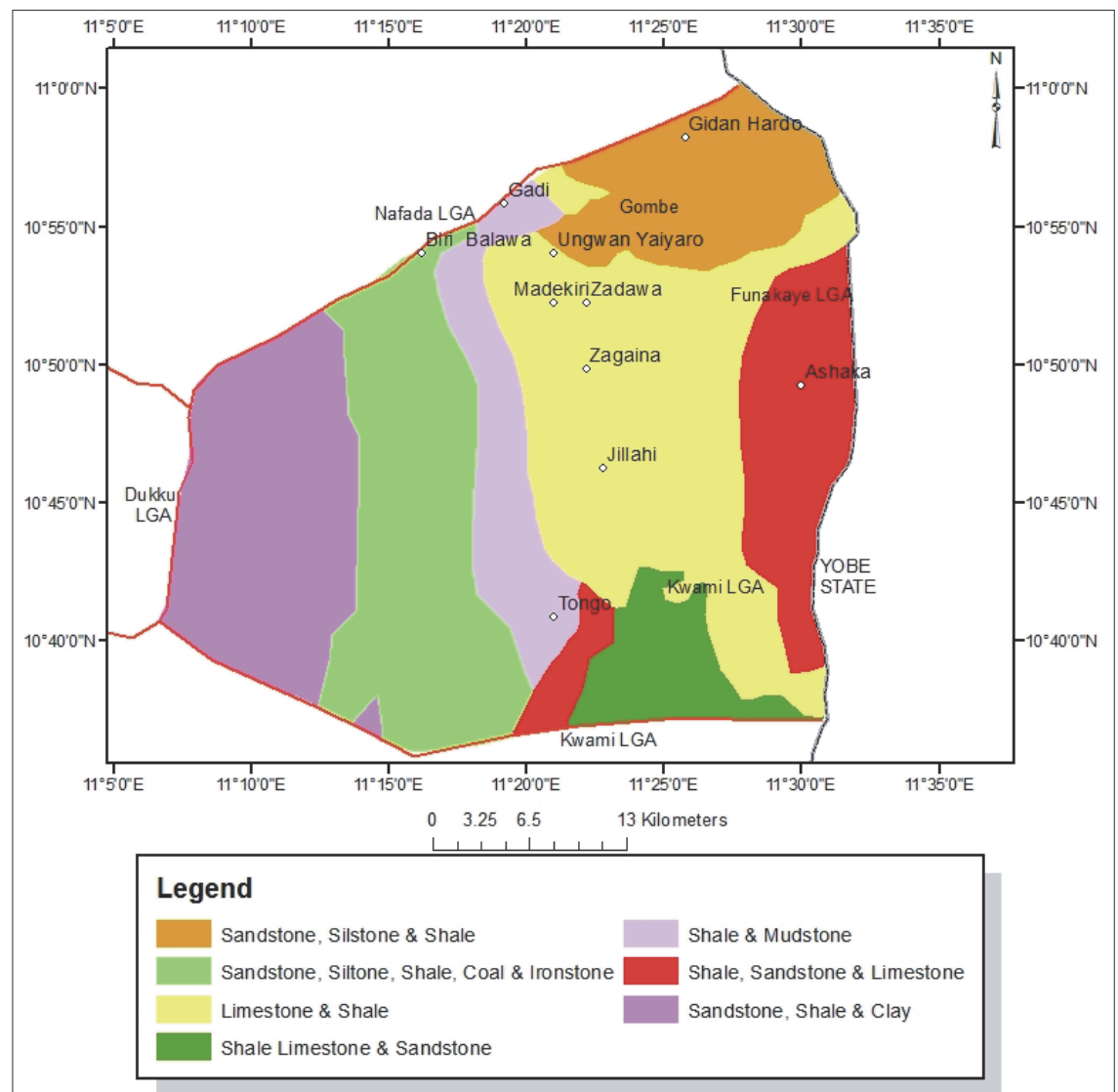

Fig. 4e: Geology of Funakaye LGA

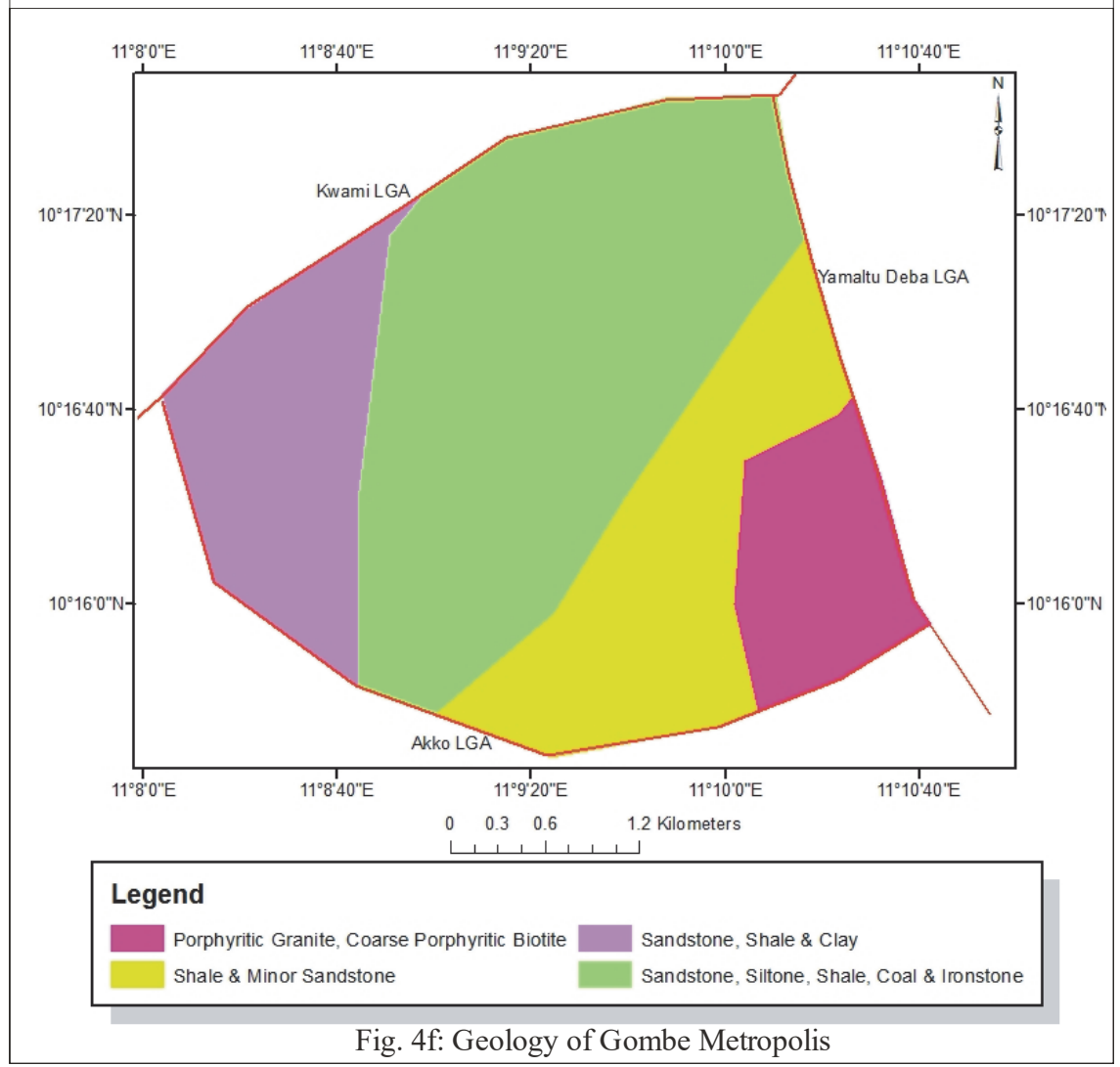

Figure 4e\&4f. Geology of Funakaye \& Gombe Metropolis 


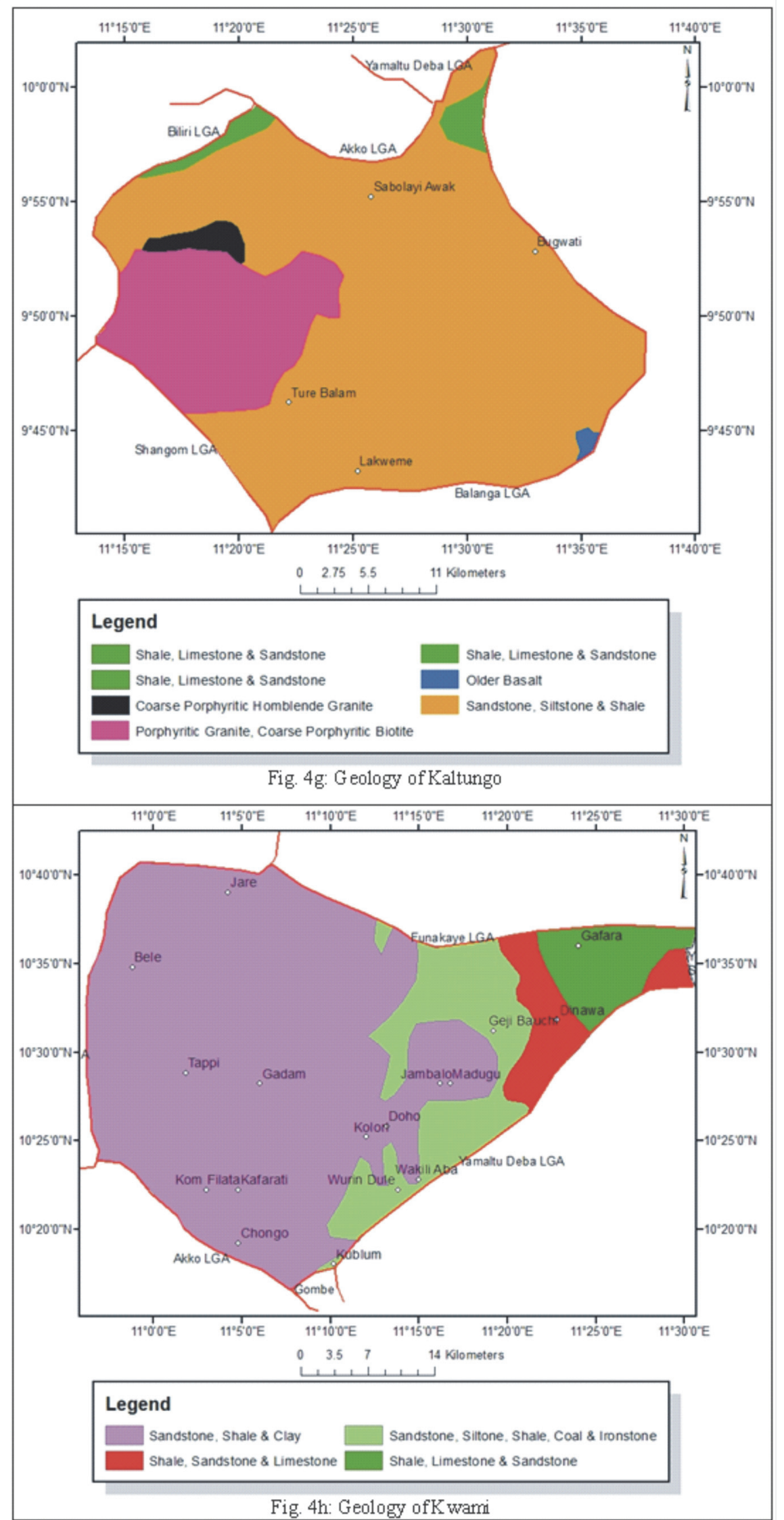

Figure $4 \mathrm{~g} \& 4 \mathrm{~h}$. Geology of Kaltungo \& Kwami LGAs 


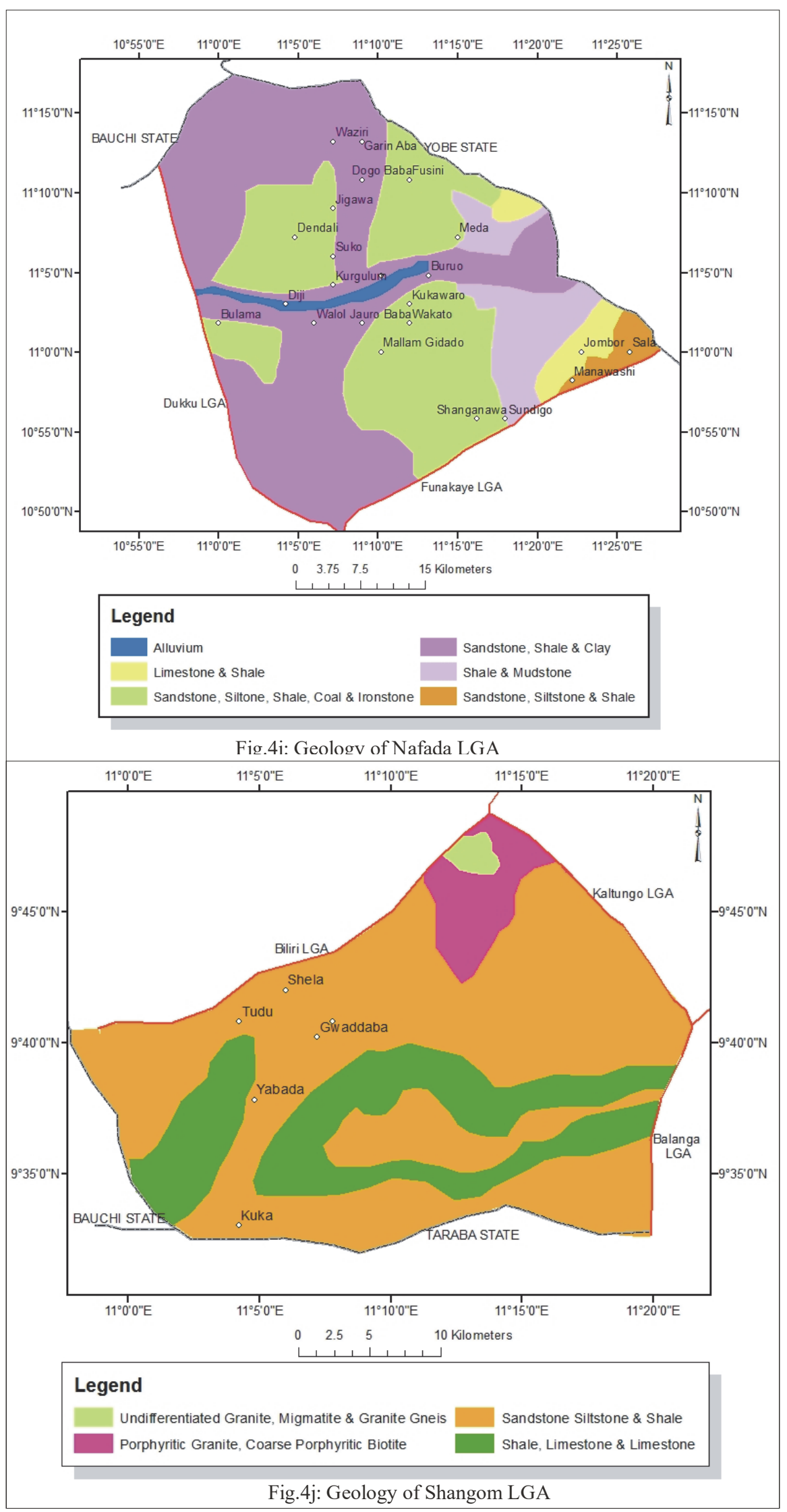

Figure $4 \mathrm{i} \& 4 \mathrm{j}$. Geology of Nafada \& Shangom LGAs 


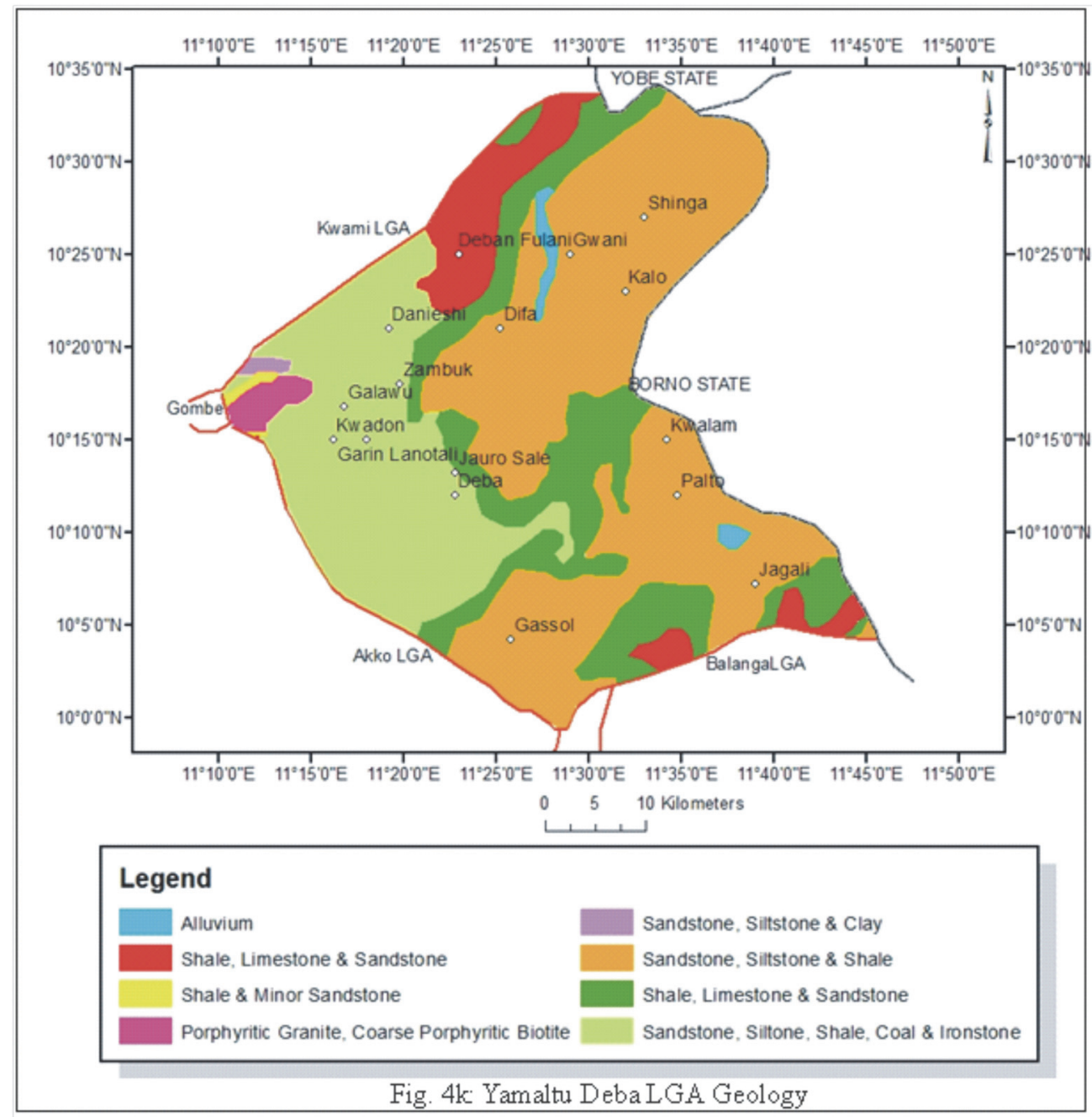

Figure 4k. Geology of Yamaltu Deba LGA

\section{Spatial Analysis of the Soils of Gombe State}

There are eleven soil units in Gombe state. That is, (i) Fluvisols (ii) Leptosols (iii) Nitisols, (iv) Regosols (v) Leptosols (vi) Cambisols and Luvisols (vii) Regosols and Cambisols (viii) Leptosols and Regosols (ix) Luvisols and Leptosols (x) Luvisols and Cambisols and (xi) Luvisols and Vertisols. Out of these eleven units, six are combinations of different soil units. Cambisols was discovered to be the only soil unit that do not stand alone but was mixed with other soil units such as Luvisols and Regosols.

Nitisols was found to cover almost half of the State (41.99\%) as revealed from Fig. 3 and Table 4. Nitisols are found mainly on higher altitudes, no wonder Nitisols is found in the western part of the state that is mainly dominated by Dukku hills. They are perhaps the most inherently fertile of the tropical soils because of their high nutrient content and deep, permeable structure. They are exploited widely for plantation agriculture. The suitability of Nitisols for plantation agriculture might have contributed to the establishment of two out of the three most important forest reserves within the Nitisols soil unit; that is, Wawa forest Reserve which lies in Dukku and Nafada LGAs as well as Lembi Forest Reserve in Akko LGA (Lazarus, 2016).

In terms of area land mass, Leptosols is the second largest soil unit in Gombe State. According to Food and Agricultural Organization FAO (2017) Leptosols are soils with a very shallow profile depth and they often contain large amounts of gravel. They typically remain under natural vegetation, being especially susceptible to erosion, desiccation, or water logging, depending on climate and topography. Leptosols are approximately equally distributed among high mountain areas. The mountainous southern part of Gombe State especially Balanga, Shangom and Kaltungo LGAs are mainly covered by Leptosol soil unit. The ever soil erosion prone areas in Akko LGA is also covered by the soil unit. 
The cement producing area of Funakaye LGA is mainly covered by Luvisols, Cambisolssols or a combination of both. Regosols are young, mineral soils (Burl et al., 2016). Regosols are extensive in eroding lands, in particular in arid and semi-arid areas and in mountain regions. The mixed mineralogy, high nutrient content, and good drainage of these soils make them suitable for a wide range of agriculture, mixed clay accumulation that has high levels of available nutrient ions comprising calcium, magnesium, sodium, or potassium. Luvisols are often associated with Cambisols. Fluvisols are found on alluvial plains. Under natural conditions periodical flooding is fairly common.

Gombe is the largest grower of cotton in Nigeria with an output of 500,000 metric tonnes per annum Voice of Gombe (2013). This largely depend on the suitable soil types for crop production in State. For instance, (Ikusemoran \& Tammi, 2009), opined that Cambisols, Vertisols and Fluvisols are suitable for cotton production. These soil types cover some parts of Yamaltu Deba, Akko and Gombe which also reflects the area where cotton production in Gombe State is prominent. The spatial coverage of each of the soil units in Gombe State and in each of the LGAs is presented in Figs. 6a to 6k and Table 4.

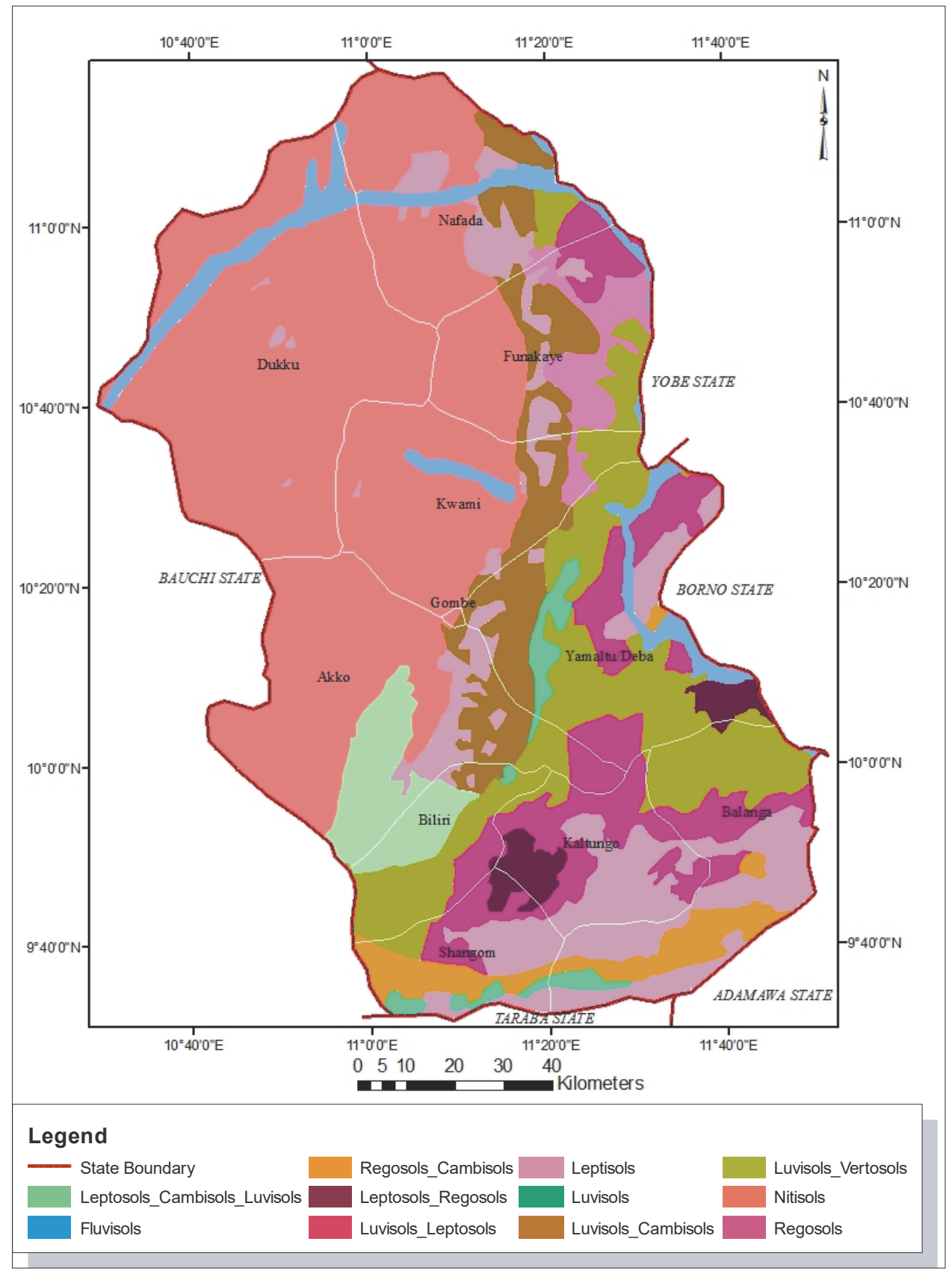

Figure 5. Soil Units in Gombe State 


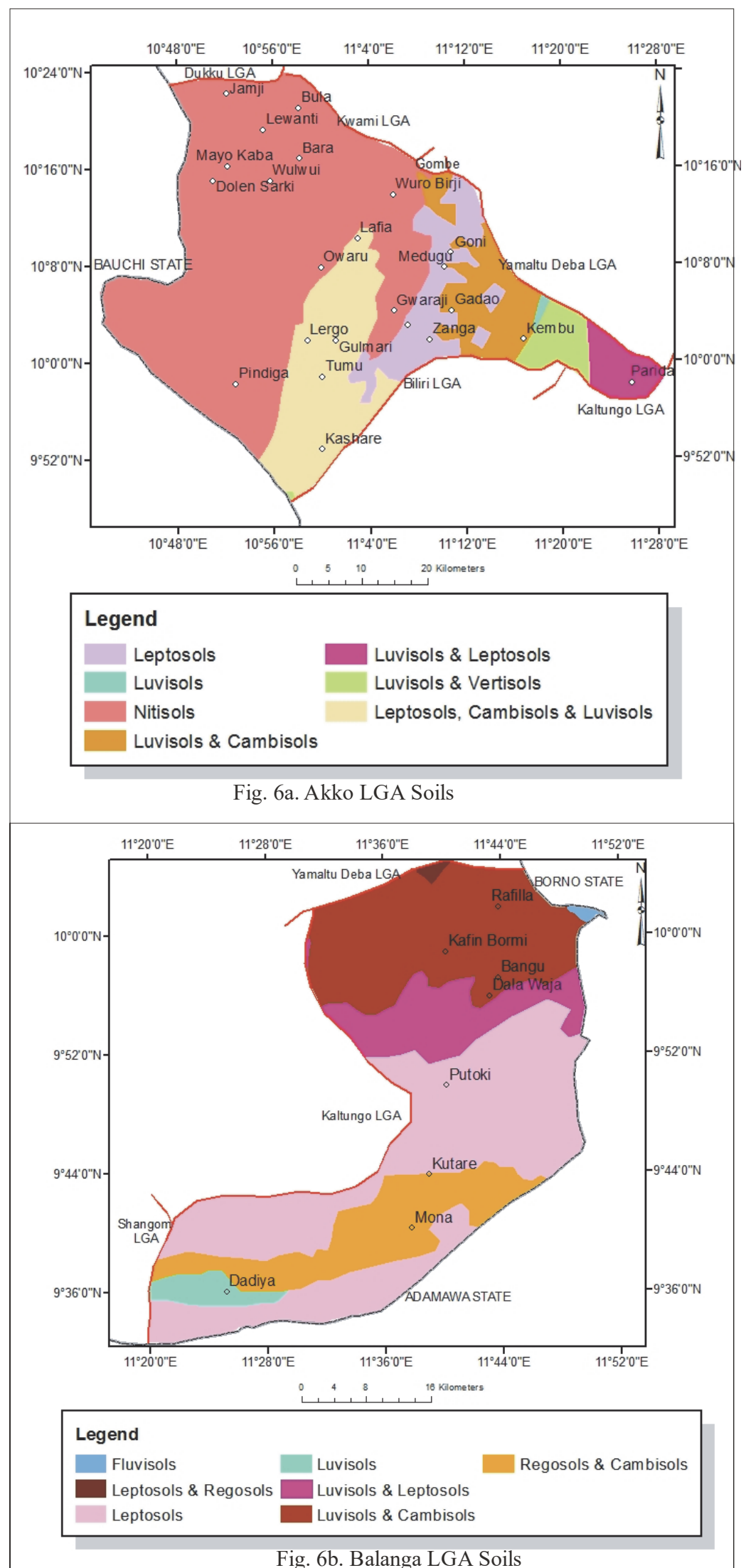

Figure 6a\&6b. Soils of Akko \& Balanga LGAs 


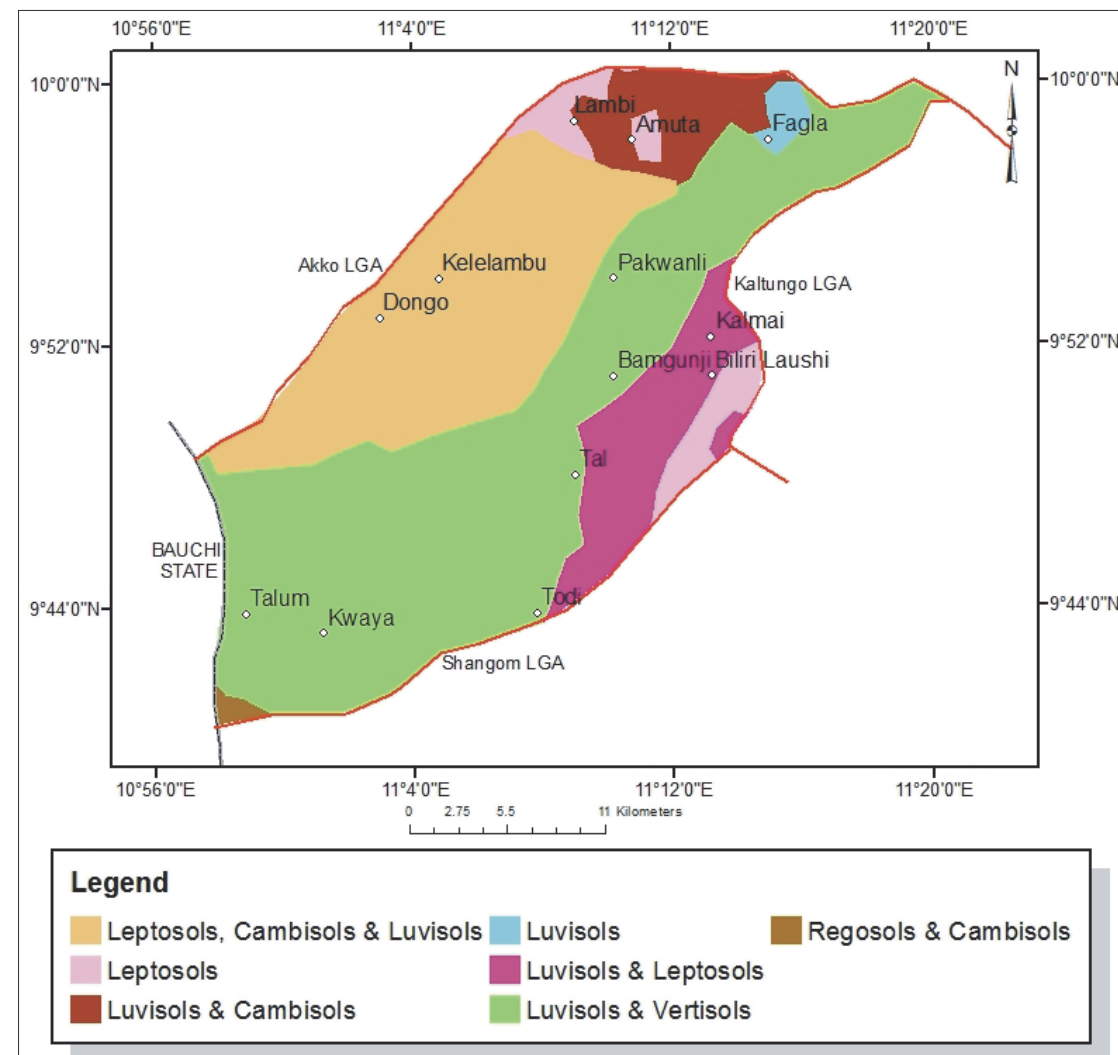

Fig. 6c. BiliriLGA Soils

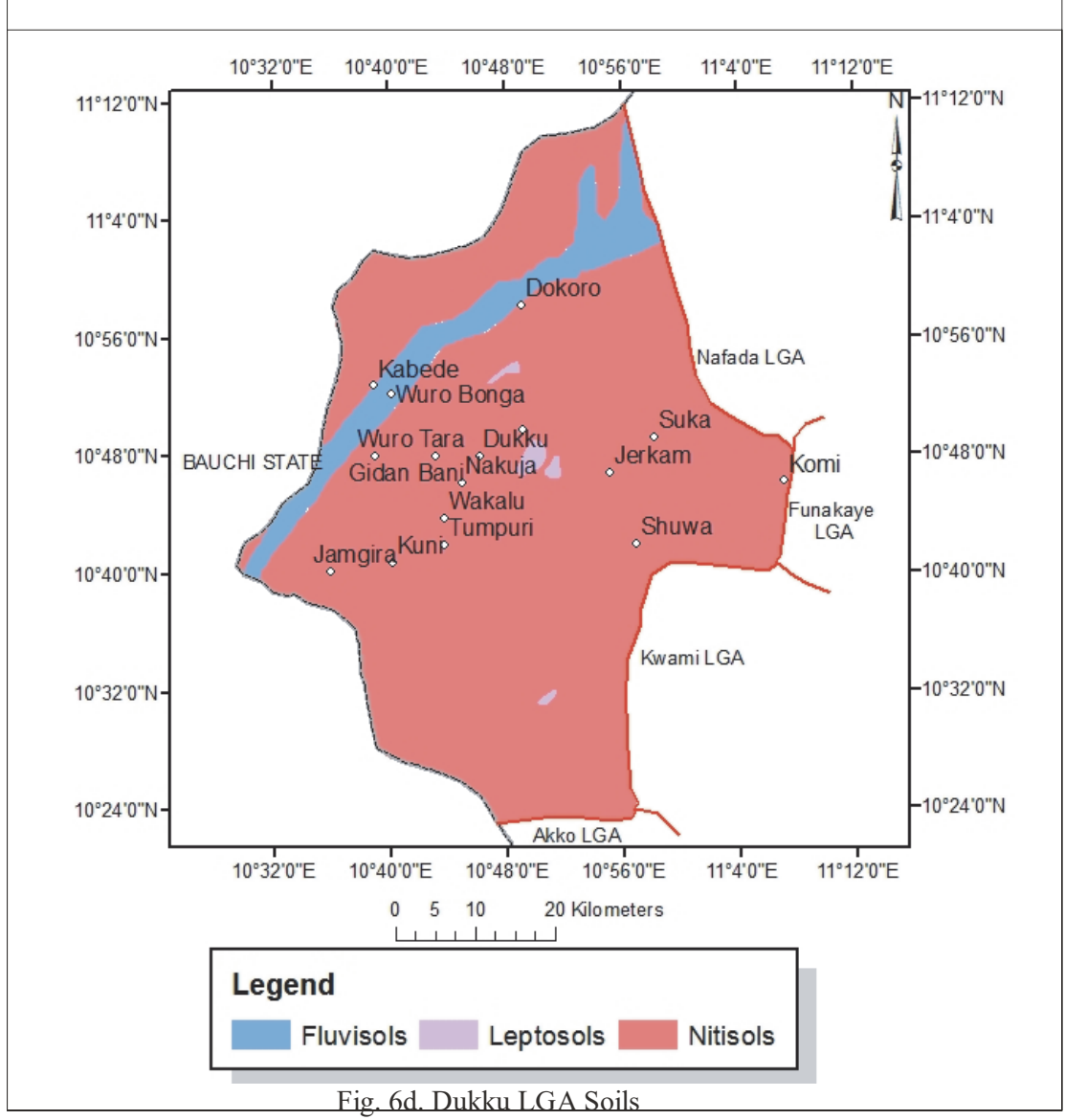

Figure $6 c \& 6 d$. Soils of Biliri \& Dukku LGAs 


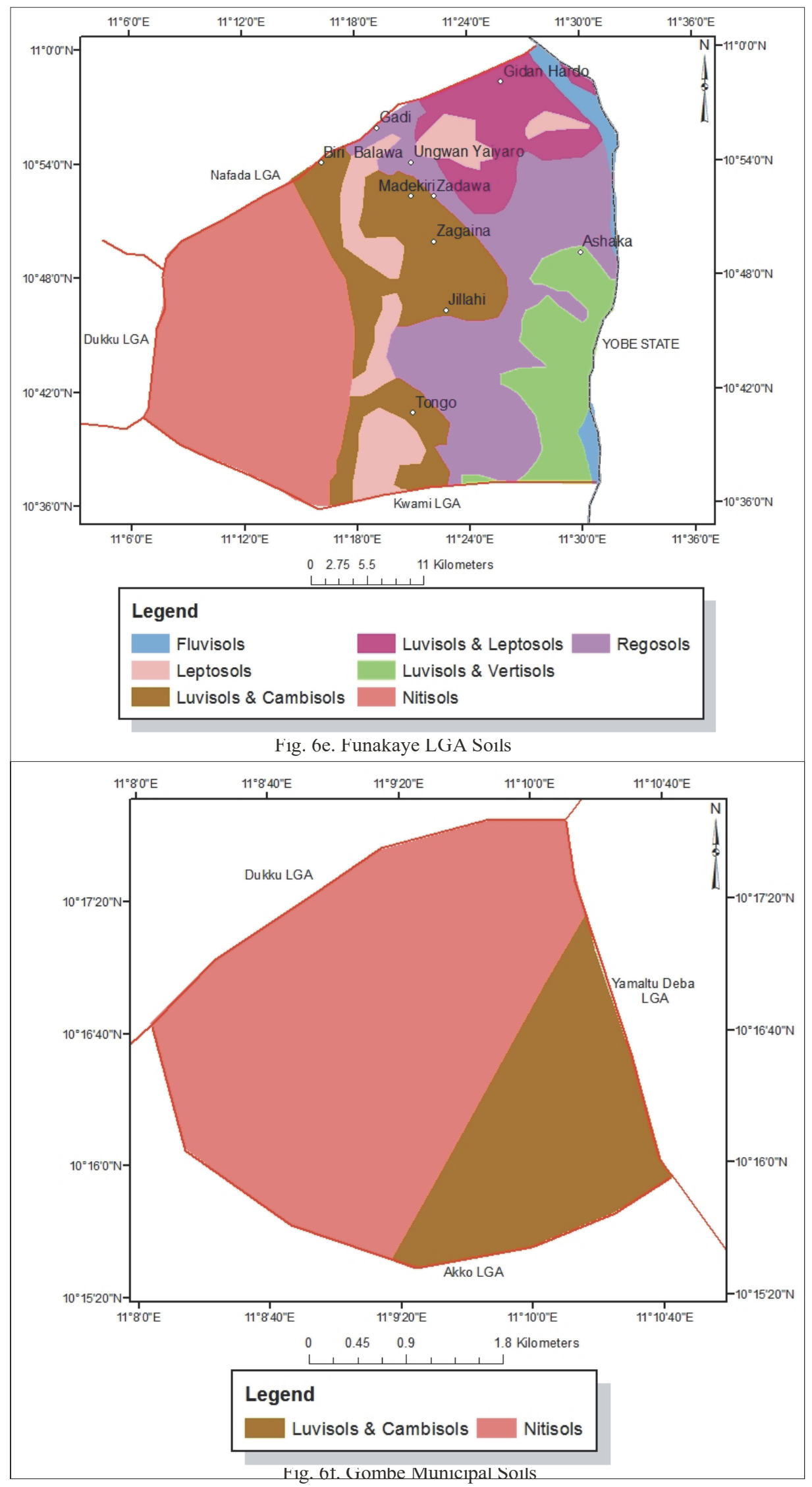

Figure 6e\&6f. Soils of Funakaye LGA \& Gombe Municipal 


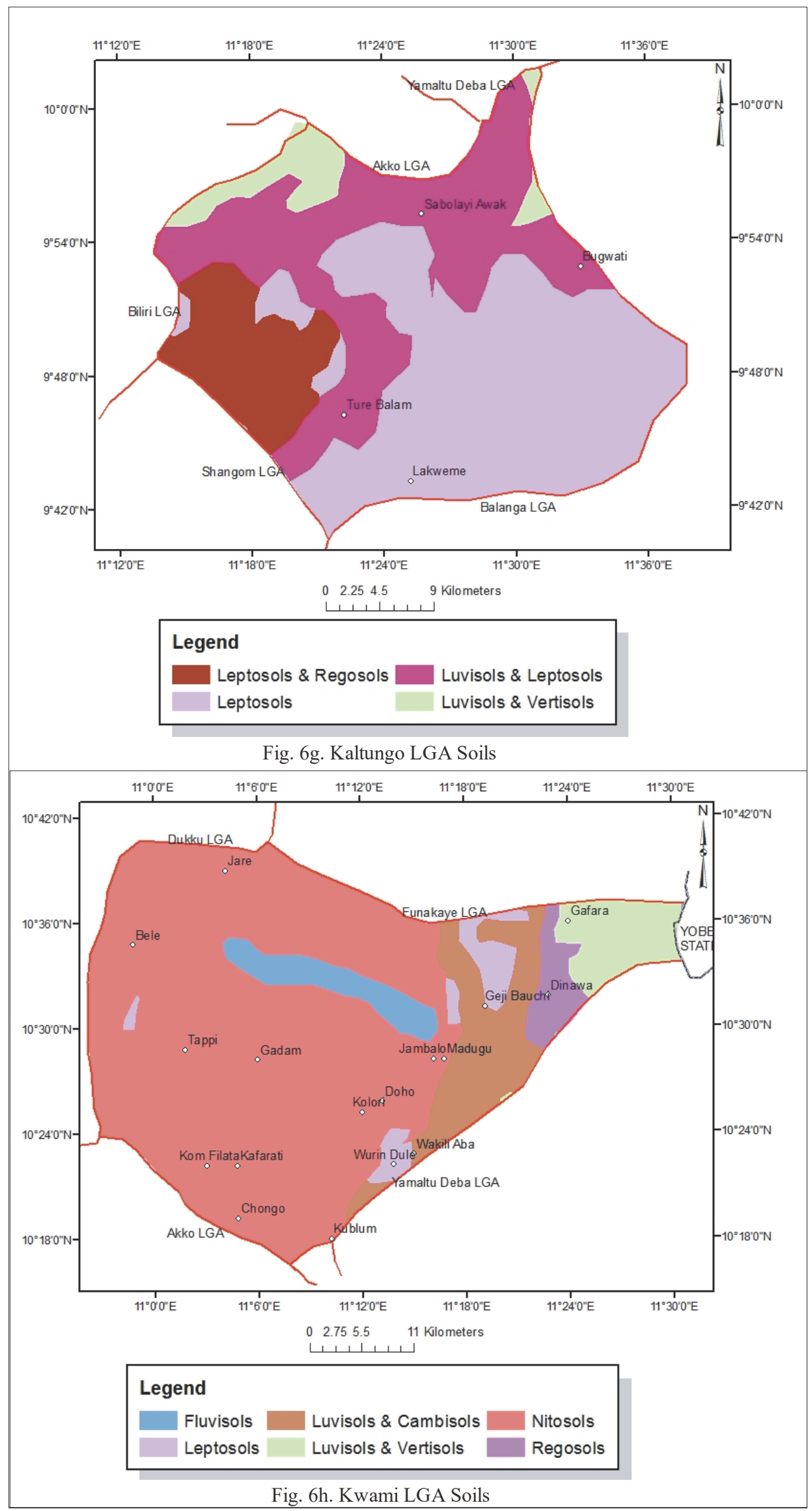

Figure $6 \mathrm{~g} \& 6 \mathrm{~h}$. Soils of Kaltungo \& Kwami LGAs 


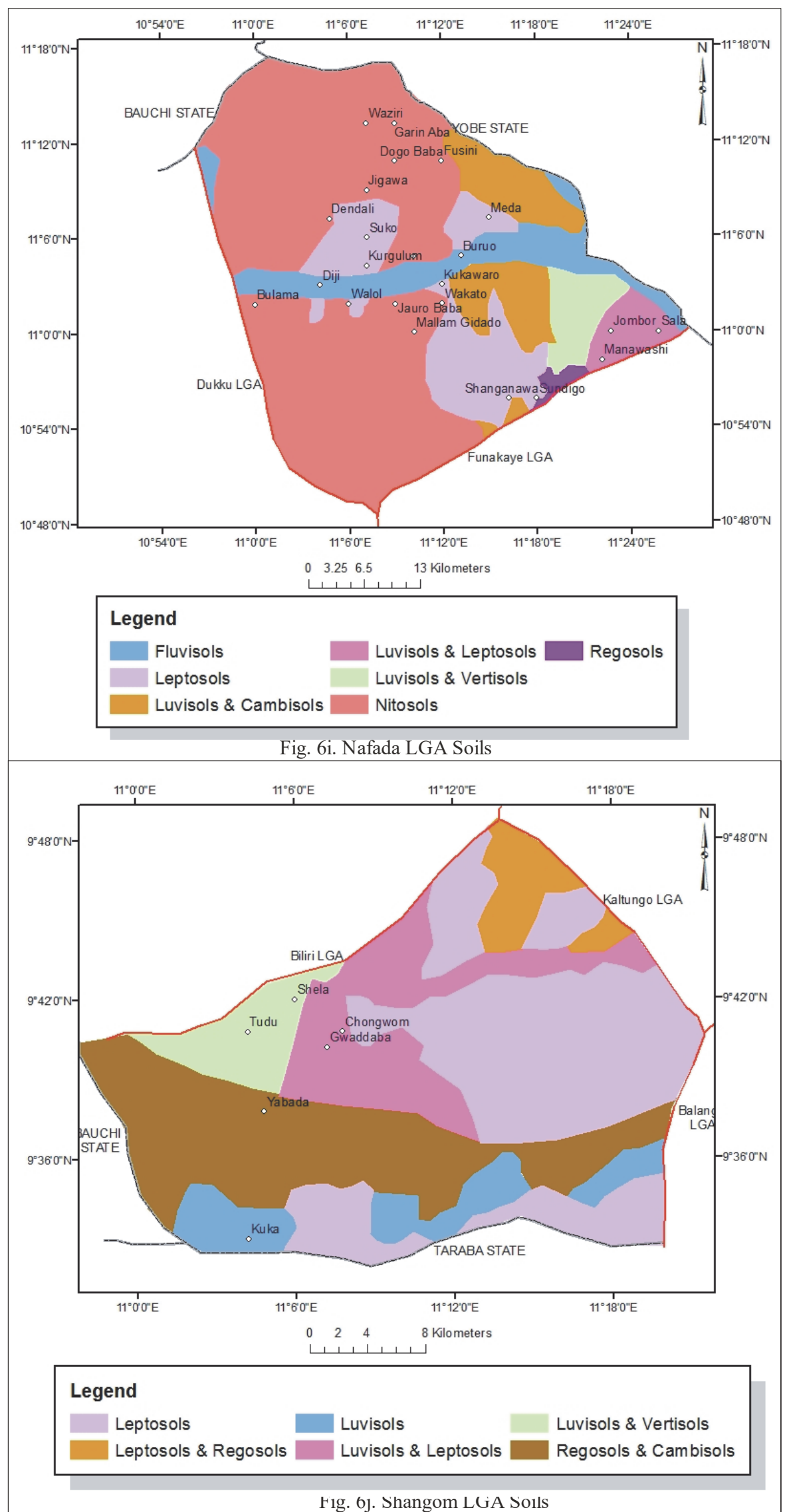

Figure 6i\&6j. Soils of Nafada \& Shangom LGAs 


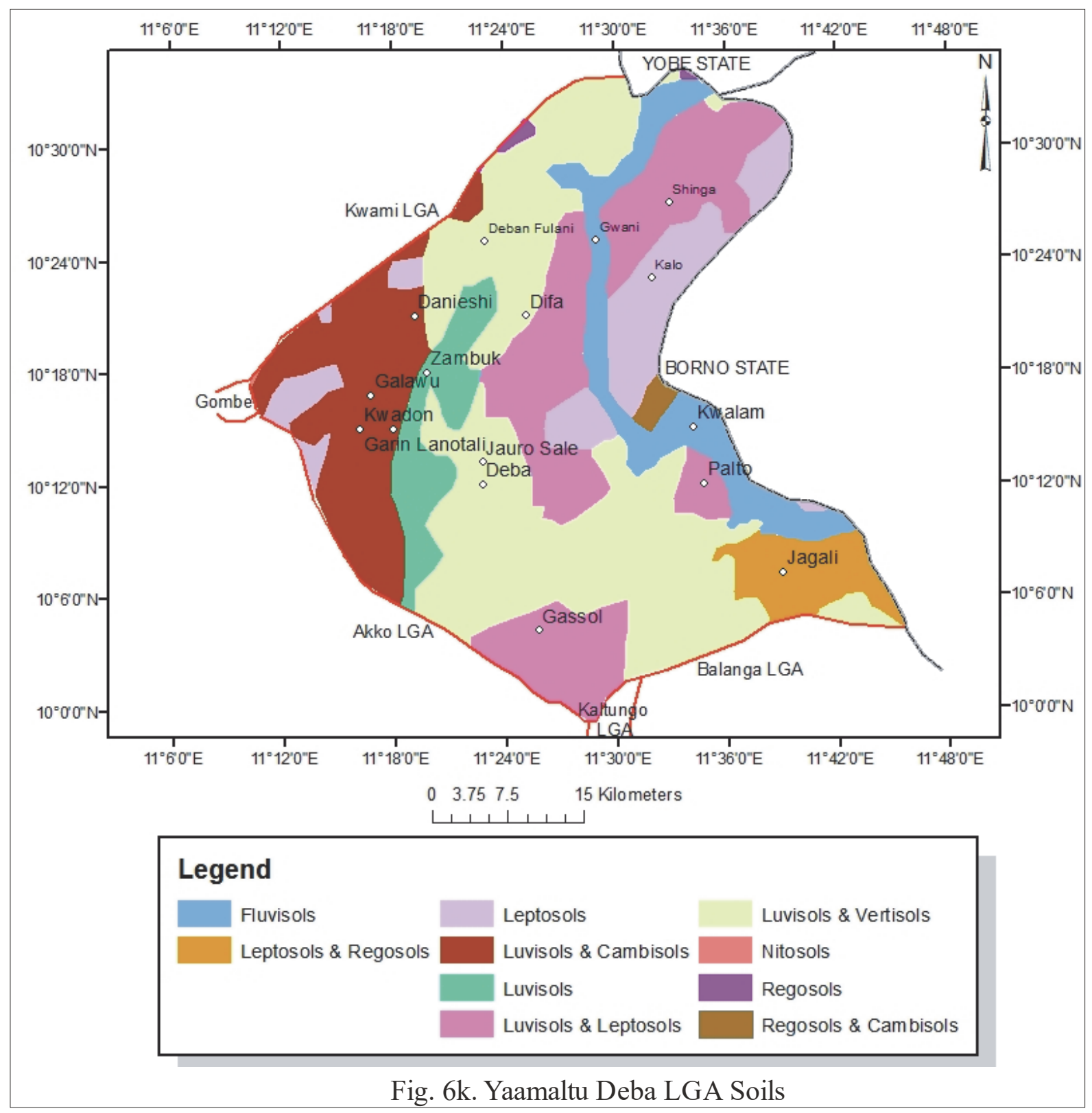

Figure 6k. Soils of Yamaltu Deba LGA 
Table 5. Spatial Distribution of the Soil Units in each LGA in Gombe State

\begin{tabular}{|c|c|c|c|c|c|c|c|c|c|c|c|}
\hline LGAs & Fluvisols & Leptosols & Luvisols & Nitisols & Regosols & \begin{tabular}{|l|} 
Leptosols, \\
Cambisols \\
$\&$ \\
Luvisols \\
\end{tabular} & $\begin{array}{l}\text { Regosols } \\
\& \\
\text { Cambisols }\end{array}$ & $\begin{array}{l}\text { Leptosols } \\
\& \\
\text { Regosols }\end{array}$ & $\begin{array}{l}\text { Luvisols } \\
\& \\
\text { Leptosols }\end{array}$ & $\begin{array}{l}\text { Luvisols } \\
\& \\
\text { Cambisols }\end{array}$ & $\begin{array}{l}\text { Luvisols } \\
\& \\
\text { Vertosols }\end{array}$ \\
\hline Akko & \multirow[b]{2}{*}{ - } & 229.1 & 5.56 & 1536.67 & \multirow[b]{2}{*}{ - } & 427.77 & \multirow[b]{2}{*}{ - } & \multirow[b]{2}{*}{ - } & 84.63 & 182.53 & 87.31 \\
\hline $\begin{array}{l}2553.57 \mathrm{k} \\
\mathrm{m}^{2}\end{array}$ & & $8.97 \%$ & $0.22 \%$ & $60.18 \%$ & & $16.75 \%$ & & & $3.31 \%$ & $7.15 \%$ & $3.42 \%$ \\
\hline Balanga & 4.91 & 633.82 & 49.51 & \multirow[b]{2}{*}{ - } & \multirow[b]{2}{*}{ - } & \multirow[b]{2}{*}{ - } & 290.72 & 6.29 & 227.96 & \multirow[b]{2}{*}{ - } & 453.27 \\
\hline $\begin{array}{l}1666.48 \\
\mathrm{~km}^{2}\end{array}$ & $0.29 \%$ & $38.03 \%$ & $2.97 \%$ & & & & $17.45 \%$ & $0.37 \%$ & $13.68 \%$ & & $27.20 \%$ \\
\hline Biliri & \multirow{2}{*}{-} & 36.54 & 8.76 & \multirow{2}{*}{ - } & \multirow{2}{*}{-} & 213.81 & 4.09 & \multirow{2}{*}{-} & 87.54 & 36.43 & 386.85 \\
\hline 774.02 & & 4.72 & $1.13 \%$ & & & $27.62 \%$ & $0.53 \%$ & & $11.31 \%$ & $4.71 \%$ & $49.99 \%$ \\
\hline Dukku & 272.72 & 20.09 & \multirow[b]{2}{*}{ - } & 3071.67 & \multirow[b]{2}{*}{ - } & \multirow[b]{2}{*}{ - } & \multirow[b]{2}{*}{-} & \multirow[b]{2}{*}{ - } & \multirow[b]{2}{*}{ - } & \multirow[b]{2}{*}{ - } & \multirow[t]{2}{*}{ 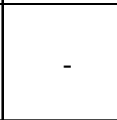 } \\
\hline $\begin{array}{l}3364.48 \\
\mathrm{~km}^{2}\end{array}$ & $8.11 \%$ & $0.60 \%$ & & $91.30 \%$ & & & & & & & \\
\hline Funakaye & 34.31 & 137.31 & \multirow[b]{2}{*}{-} & 456.37 & 351.35 & \multirow[b]{2}{*}{-} & \multirow[b]{2}{*}{ - } & \multirow[b]{2}{*}{-} & 133.95 & 219.56 & 142.83 \\
\hline $\begin{array}{l}1475.68 \\
\mathrm{~km}^{2}\end{array}$ & $2.33 \%$ & $9.30 \%$ & & $30.93 \%$ & $23.81 \%$ & & & & $9.08 \%$ & $14.88 \%$ & $9.68 \%$ \\
\hline Gombe & \multirow{2}{*}{-} & \multirow{2}{*}{-} & \multirow{2}{*}{-} & 9.88 & \multirow{2}{*}{ - } & \multirow{2}{*}{ - } & \multirow{2}{*}{ - } & & & 3.91 & \\
\hline $13.79 \mathrm{~km}^{2}$ & & & & $71.65 \%$ & & & & - & - & $28.35 \%$ & - \\
\hline Kaltungo & & 387.66 & & & & & & 126.69 & 422.57 & & 60.74 \\
\hline $\begin{array}{l}997.66 \\
\mathrm{~km}^{2} \\
\end{array}$ & - & $38.86 \%$ & - & - & - & - & - & $12.70 \%$ & $42.36 \%$ & - & $6.09 \%$ \\
\hline Kwami & 70.09 & 58.83 & & 1168.64 & 53.41 & & & & & 187.75 & 93.77 \\
\hline $\begin{array}{l}1632.49 \\
\mathrm{~km}^{2}\end{array}$ & $4.29 \%$ & $3.60 \%$ & - & $71.59 \%$ & $3.27 \%$ & - & - & - & - & $11.50 \%$ & $5.74 \%$ \\
\hline Nafada & 173.1 & 254.84 & & 1002.19 & 14.54 & & & & 59.4 & 186.63 & 75.85 \\
\hline $\begin{array}{l}1766.55 \\
\mathrm{~km}^{2}\end{array}$ & 9.8 & 14.42 & - & 56.73 & 0.82 & - & - & - & 3.36 & 10.56 & 4.29 \\
\hline Shangom & & 289.79 & 74.27 & & & & 207.18 & 45.92 & 150.23 & & 51.49 \\
\hline $\begin{array}{l}818.88 \\
\mathrm{~km}^{2}\end{array}$ & - & $35.39 \%$ & $9.07 \%$ & - & - & - & $25.30 \%$ & $5.61 \%$ & $18.35 \%$ & - & $6.29 \%$ \\
\hline Y/Deba & 191.73 & 216.72 & 123.01 & 1.31 & 8.15 & & 14.46 & 102.57 & 478.41 & 296.8 & 761.84 \\
\hline $2195 \mathrm{~km}^{2}$ & $8.73 \%$ & $9.87 \%$ & $5.60 \%$ & $0.06 \%$ & 0.37 & - & 0.66 & 4.67 & 21.8 & 13.52 & 34.71 \\
\hline Total & 746.86 & 2264.7 & 261.11 & \begin{tabular}{|l|l|}
7246.73 \\
\end{tabular} & 427.45 & 641.58 & 516.45 & 281.47 & 1644.69 & \begin{tabular}{|l|}
1113.61 \\
\end{tabular} & 2113.95 \\
\hline G/Total & & & & & & & & & & & \begin{tabular}{|l|}
17258.6 \\
\end{tabular} \\
\hline Total & $4.33 \%$ & $13.12 \%$ & $1.51 \%$ & $41.99 \%$ & $2.48 \%$ & $3.71 \%$ & $2.99 \%$ & $1.63 \%$ & $9.53 \%$ & $6.45 \%$ & $12.25 \%$ \\
\hline G/Total & & & & & & & & & & & $100 \%$ \\
\hline
\end{tabular}

Some of the settlements in each of the soils and geologic units are presented in Figs. 7a and $7 \mathrm{~b}$ for easy identification of the settlements in each geologic or soils. 


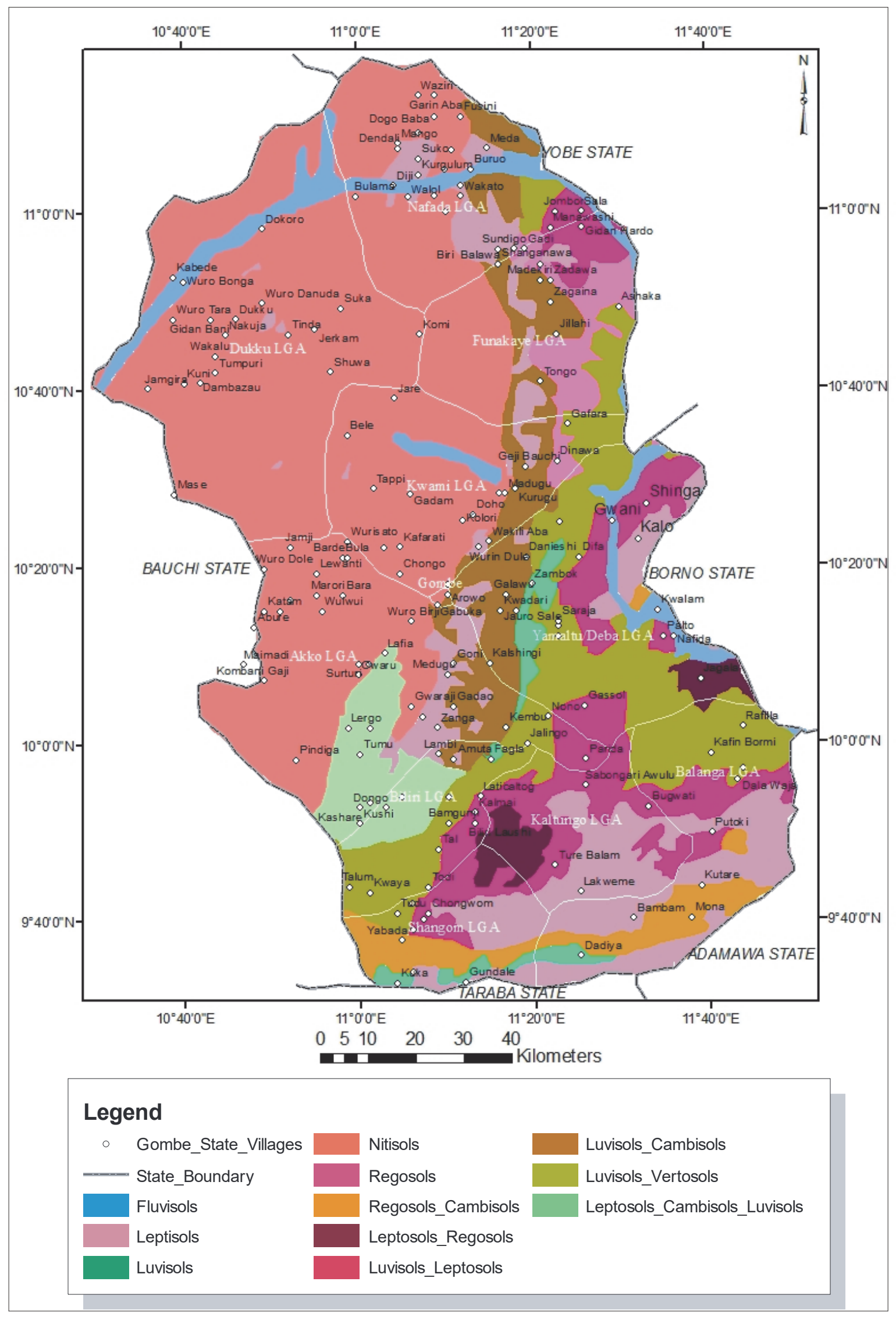

Figure 7a. Some Settlements on the Soils of Gombe State 


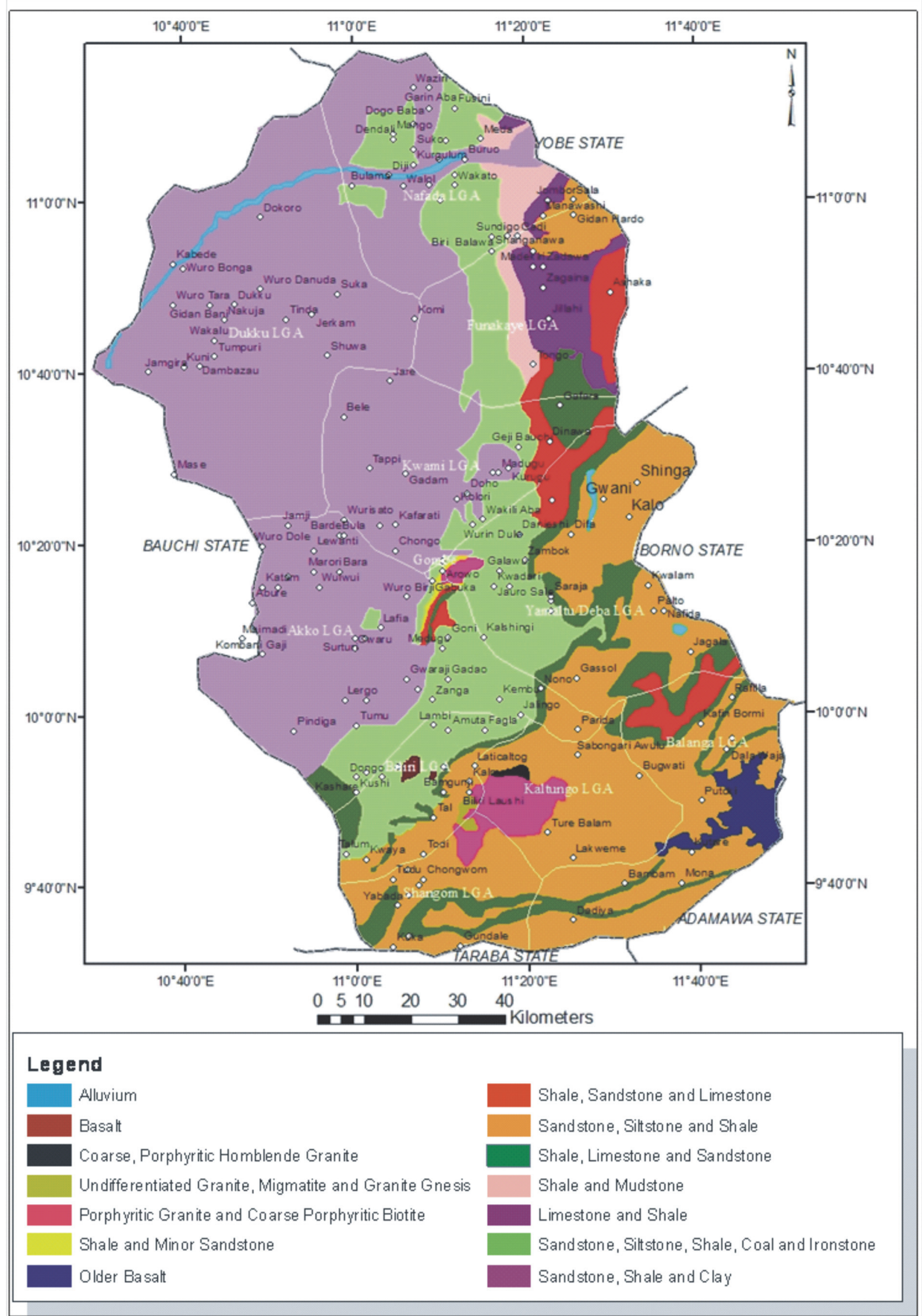

Figure 7b. Some Settlements on the Geology of Gombe State 


\section{Conclusion}

The spatial distributions of the soils and geologic units in Gombe State in general and in each of the LGAs in the State have been demonstrated in this paper. The quantity of the spatial coverage of each unit in the soils and geology in the State and in each LGAs have also been carried out. It is hoped that researchers and other stakeholders who are interested in using spatial distribution of the soil and geology of smaller units like LGAs in the State will find this work very useful. The result of the study revealed similarity between the spatial distribution of the geologic and soil units in the State. For instance, the western part of the State is covered by only one soil (Nitisols) or geologic (Sandstone, Shale and Clay) units while the eastern and southern parts contain the other soil and geological units. The result also shows that Gombe State has fourteen (14) geologic units. However, out of the 14 geologic units, almost half of the State (41.75\%) is covered by Sandstone, Shale and Clay unit, while eleven soil units exist in the State with Sandstone, Shale and Clay unit alone covering $41.99 \%$ of the State. The use of geospatial techniques for spatial assessments and quantification in this paper has also proven to be better, faster and more accurate than the manual methods. It could have been very difficult to map, delineate and calculate the soils and geologic units with accuracy of spatial locations of other features like settlements and political boundaries if manual techniques were used. The major limitation of this paper is the use of already made soil and geology maps which considered some areas as having several units such luvisols and vertisols in soil or shale and mudstone in the geologic unit.

This paper is also expected to minimize the time, cost and energy on mineral exploration and site suitability for crop production activities in the State because once the suitable geology or soils for a particular mineral or crop is identified on the map, it will limit the exploration or suitability study to only the areas where such geologic unit or soil is endowed. Though the sources of the maps were highly reliable, but it could have been better if the maps were generated using geospatial techniques. It is therefore suggested that further studies should be carried out on geospatial techniques for mapping soil and geologic units in the State. Delineation and mapping of the soils, relief, drainage, geology etc. of the agricultural and mining zones in the State to serve as data bank for further researchers or other users in general.

\section{Recommendations}

From the results and findings of this study, the following recommendations are made:

(i) Geospatial mapping of the soils and geology of the agricultural zones of Gombe state should be carried out so as to ease the problems of delineation and extraction of the zones from the available entire Gombe state.

(ii) Generation of maps of the agricultural and mining zones in the state comprising of major features like soil, geology, relief, drainage, population density, transport, settlement among others to serve as data bank

(iii) Further research should also be carried to actually delineate the areas that are considered to comprise more than a unit except where those units are actual mixed

(iv) The generated soil and geologic maps of the State are expected to be considered for mineral exploration and crop suitability assessments in order to reduce time, cost and energy that would be incurred if the entire state is assessed.

\section{References}

Abubakar, B. Y. (2013). North-east economic summit: Up-scaling agricultural-business in the north-east through innovative value and agricultural clusters. A paper presented by the executive secretary, agricultural research council of Nigeria at a workshop organized by the agricultural research council of Nigeria at Mabushi Abuja between $3^{\text {rd }}$ and $4^{\text {th }}$ Dec. 2013.

Ahmed, I. H. (2007). Geology and economic potential of barite mineralization on Gombe inlier, Gombe State, Nigeria. Retrieved from http://www.grin.com/en/e-book/212495/geology-and-economic-potential-of-baritemineralization-on-gombe-inlier

Akande, S. O., Ojo, O. J., Erdtmann, B. D., \& Hetenyi, M. (1998). Paleo-environments, source rock potential and thermal maturity of the Upper Benue rift basins, Nigeria: Implications for hydrocarbon exploration. Organic Geochemistry, 29(1-3 -3 pt 1), 531-542.

Babatunde, A. (2016). Depositional environments of late cretaceous Gongila and Fika formations, Chad (Bornu) Basin, northeast Nigeria. Marine and petroleum Geology, 75(August), 100-116.

Burl, D. M., Ward, C., \& Otto, S. (2016). Retrieved from http://link.springer.com/referenceworkentry/10.1007/978.

Carter, J. D., Barber, W., Tait, E. A., \& Jones, G. B. (1963). The Geology of parts of Adamawa, Bauchi and Borno 
Provinces in Northeastern Nigeria. Geological Survey of Nigeria Bulletin No. 30:76

FAO. (2002). Soil biodiversity and sustainable agriculture. Paper prepared as a background paper for the ninth regular session of the commission on genetic resources for food and agriculture (CGRFA) FAO-Rome, 14-18 October 2002. Retrieved from http://www.fao.org/fileadmin/templates/.../CGRFA_soilbiodsustag.doc

FAO/UNESCO/ISRC (1996). Dominant soils of Nigeria. Center for world food studies, thirteen west and central African soil correlation sub-committee meeting, Kumasi Ghana; 11-15 ${ }^{\text {th }}$ Nov; 1996.

Food and Agricultural Organization (FAO) (2017). FAO soil group. Retrieved from Retrieved from http://www.britannica.com/science/phaeozem on 19th May, 2017

Gombe State Official Website (2013). Gombe state physical setting. Retrieved January 15, 2015, from http://www.onlinenigeria.com/links/gombeadv.asp?blurb=262\#ixzz2ndQmdOJS

Gombe State Tourism Board (2013). Gombe state tourism. Retrieved May 17, 2014, from http://www.goodlife.com.ng/gltourism.php?gltourism=read\&id=75

Ikusemoran, M., \& Tammi, H. (2009). Site suitability for yam, rice and cotton production in Adamawa state: remote sensing and GIS application. Journals of environment, School of environmental sciences, FUT Yola. pp 45-58.

Ikusemoran, M., Odihi, J. O., \& Manu, H. Y. (2017). Geographical synthesis of Biu plateau. Academic Research International, 8(2), 18-34.

Ikusemoran, M., Wanah, B. B., \& Mbaya, L. A. (2016). Geospatial techniques for terrain analysis of Gombe State, Nigeria. Journal of Geography, Environment and Earth Science International, 6(1),1-20

Klinkenberg, K. (1967). The soils of the Lau-Kaltungo area: Soil survey bulletin No 36, Institute for agricultural research, Ahmadu Bello University, Zaria.

Lazarus, A. M. (2016). Analysis of forest reserves (savanna woodland) biodiversity status and rural livelihoods in Gombe State. Retrieved from http://gombestateuniversity.academia.edu/lazarusAborembaya

Mohammed, S. (2011). Economic of rain fed and irrigated rice production under upper Benue river basin development authority scheme, Dadinkowa, Gombe state, Nigeria. Continental J. Agricultural Economics, 5(1), 14-22.

National Population Commission (2006). Federal Republic of Nigeria 2006 population and housing census enumerators manual. p. 346.

Nigeria Geological Survey Agency (NGSA) (2009). Geology of Nigeria.

Portland Cement (2017). Understanding cement: Interpreting cement since (2005). Retrieved September 9, 2017, from http://www.understanding-cement.com/raw-materials.html. Retrieved 09/09/2017

Rhodes, F., \& Perlman, R. (2001). Geology. St Martin's Press. ISBN 1582381437. Retrieved from http://www.union.edu/academic_depts/geology/

Soil Science Society of America (2017). Soil and environment. Retrieved September 9, 2017, from $\mathrm{http}: / /$ soils4teachers.org/soil-and-environment

Suleiman, U. A., Hamza H., \& Zaborski, P. M. (2015). Middle cretaceous sequence stratigraphy at the Ashaka cement quarry in Gongola Basin of the Upper Benue trough, northeast Nigeria. OSR Journal of applied geology and geophysics (IOSRJAGG), 3(2), 59-67. e ISSN: 2321-0990, p-ISSN: 2321-0982.

Surveyor General of the Federation (OSGOF) (2012). Mapping and geospatial blogging competition for Nigerian students. Retrieved from http://www.osgof.com/

Udo, R. K. (1978). Geographical regions of Nigeria. London Heinemann Press, 151-154.

Voice of Gombe (2013). Agriculuture in Gombe State.

World Atlas of the Encarta Premium (2009).

\section{Copyrights}

Copyright for this article is retained by the author(s), with first publication rights granted to the journal.

This is an open-access article distributed under the terms and conditions of the Creative Commons Attribution license (http://creativecommons.org/licenses/by/4.0/). 